\title{
Superimposed Neoarchaean and Paleoproterozoic tectonics in the Terre Adélie Craton (East Antarctica): Evidence from Th-U-Pb ages on monazite and ${ }^{40} \mathrm{Ar} /{ }^{39} \mathrm{Ar}$ ages
}

\author{
Guillaume Duclaux a,b,c,*, Yann Rolland ${ }^{\mathrm{d}}$, Gilles Ruffet ${ }^{\mathrm{e}}$, René-Pierre Ménot ${ }^{\mathrm{a}}$, Stéphane Guillot ${ }^{\mathrm{f}}$, \\ Jean-Jacques Peucat ${ }^{\mathrm{e}}$, Mark Fanning ${ }^{\mathrm{g}}$, Patrice Rey ${ }^{\mathrm{b}}$, Arnaud Pêcher ${ }^{\mathrm{f}}$ \\ a Magmas et Volcans, CNRS, Université Jean Monnet, Saint Étienne, France \\ ${ }^{\mathrm{b}}$ Earth Byte Group, School of Geosciences, The University of Sydney, Sydney, NSW, Australia \\ c CSIRO Exploration and Mining, ARRC, Kensington, WA, Australia \\ d Géosciences Azur, CNRS, Université de Nice Sophia Antipolis, IRD, Nice, France \\ e Geosciences Rennes, CNRS, Université de Rennes 1, Rennes, France \\ f Laboratoire de Géodynamique des Chaînes Alpines, CNRS, Université Joseph Fourier, Grenoble, France \\ ${ }^{\mathrm{g}}$ Research School of Earth Sciences, Australian National University, Canberra, ACT, Australia
}

\section{A R T I C L E I N F O}

\section{Article history:}

Received 15 August 2007

Received in revised form

19 September 2008

Accepted 23 September 2008

\section{Keywords:}

$\mathrm{Th}-\mathrm{U}-\mathrm{Pb}$ dating of monazite

${ }^{40} \mathrm{Ar} /{ }^{39} \mathrm{Ar}$ geochronology

Polyphase tectonic evolution

Craton reactivation

Strain localization

\begin{abstract}
A B S T R A C T
In order to understand the tectonic behaviour of a stabilized Neoarchaean continental crust during subsequent tectonic activity, we investigated the composite metamorphic basement along the Terre Adélie and George Vth Land coastline, also known as the Terre Adélie Craton (East Antarctica). Two domains are recognized: (1) a Neoarchaean basement, composed of granulite rocks to the east and overlain to the west by amphibolites, and (2) two Paleoproterozoic detrital basins overly the Neoarchaean crust and extend further west. New geochronological data from the Terre Adélie Craton define a tectonic evolution with three major peaks' activity. Th-U-Pb electron probe analyses of monazite from the Neoarchaean granulites constrain the main structuration event at ca. $2.45 \mathrm{Ga}$ in agreement with zircon ages from throughout the Neoarchaean domain. Local resetting together with low temperature recrystallization of monazites occurred at ca. $1.7 \mathrm{Ga}$ along hydrated anastomozing metre-scale shear zones. New ${ }^{40} \mathrm{Ar} /{ }^{39} \mathrm{Ar}$ ages obtained by stepwise heating techniques on amphibole, biotite and muscovite from both the Neoarchaean basement and the Paleoproterozoic basins, illustrate the differential evolutions of basement and its sedimentary cover during the major $1.7 \mathrm{Ga}$ transpressive event. A final event at ca. $1.55-1.50 \mathrm{Ga}$ is only recognized close to the Mertz Shear Zone $\left(145^{\circ} \mathrm{E}\right)$ bounding the Terre Adélie Craton to the East. The new data allow us to propose detailed geological pictures of the Terre Adélie Craton geodynamic evolution, from the Neoarchaean to the Mesoproterozoic.
\end{abstract}

Crown Copyright @ 2008 Published by Elsevier B.V. All rights reserved.

\section{Introduction}

Throughout Earth history and its related secular cooling, the deformation style of continental crust evolved in response to the crustal thermal regime and its stress state (Rey and Houseman, 2006). In recent orogens, cool and strong plates accommodate convergence through a combination of crustal underthrusting along narrow mountain belts and lateral escape of continental blocks along lithospheric strike-slip faults (Tapponnier et al., 1982). In contrast, Archaean continental lithospheres were warmer

* Corresponding author at: CSIRO Exploration and Mining, Australian Resources Research Centre, PO Box 1130, Bentley, WA 6102, Australia. Fax: +61 864368555. E-mail address: guillaume.duclaux@csiro.au (G. Duclaux). and accommodated convergence through homogeneous thickening and lateral ductile flow (Rey and Houseman, 2006; Cruden et al., 2006; Cagnard et al., 2006). Subsequently, unloading of warm orogenic domains during the decrease of the converging tectonic force favored orogen-parallel constrictional flow of the crust and tangential motions (Duclaux et al., 2007). The transition from Archaean to modern style geodynamics would appear to take place at around $2.0 \mathrm{Ga}$ (Hamilton, 1998), coincident with the first occurrence of high pressure-low temperature subductionrelated eclogites (Collins et al., 2004). Composite Archaean and Paleoproterozoic cratons, which underwent minor subsequent tectonic reactivation, are ideal terrains to study this major geodynamic evolution.

The Terre Adélie Craton (TAC) (Fig. 1) is composed of two crustal domains (Monnier et al., 1996): (1) a Neoarchaean to Siderian 


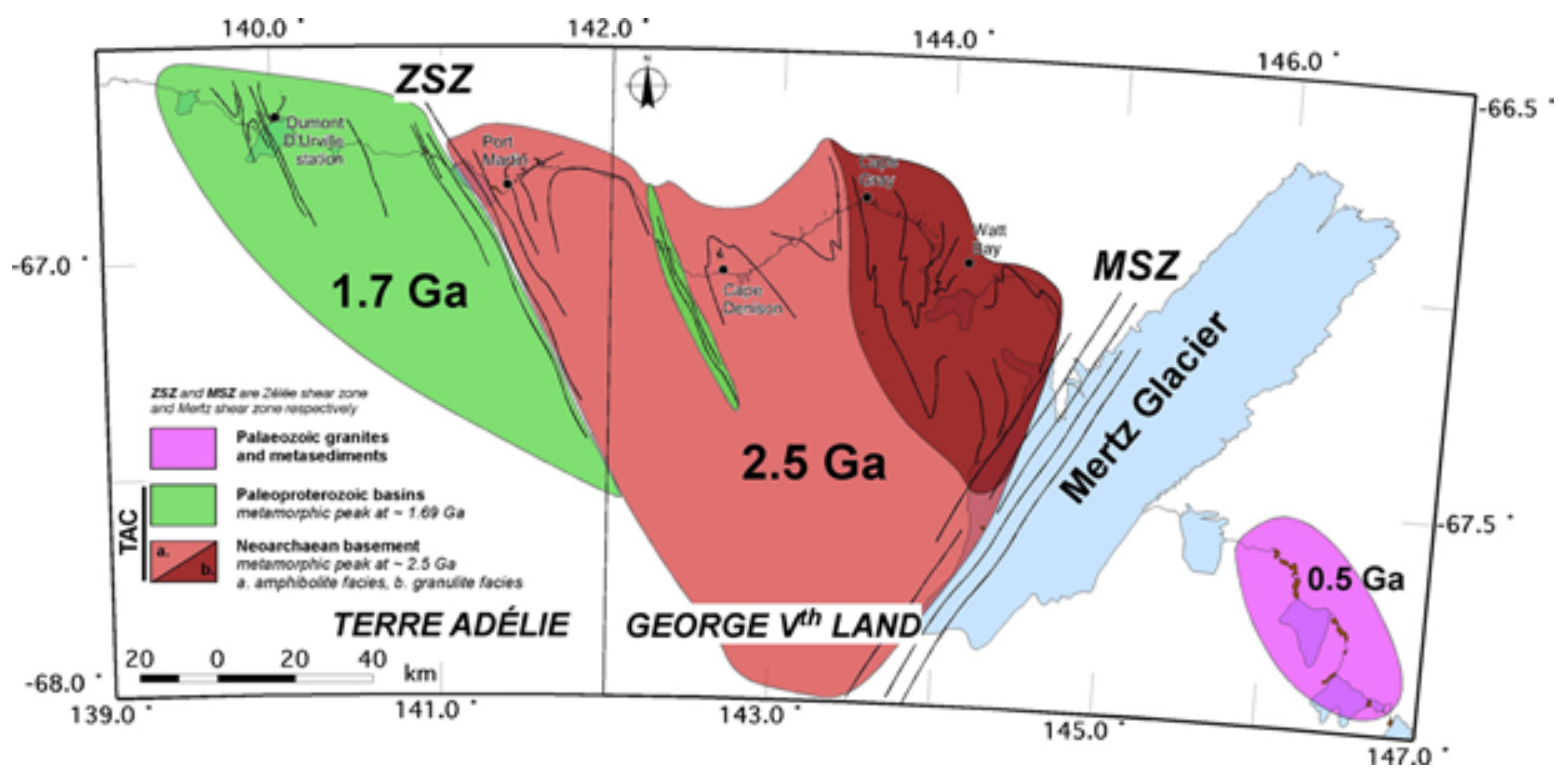

Fig. 1. Synthetic geological map of the Terre Adélie Craton (after Ménot et al., 2007). Green areas are Paleoproterozoic in age and correspond to the Dumont D’Urville (DDU) and Cape Hunter $(\mathrm{CH})$ Basins; reddish areas are Archaean in age, the darker part to the east refers to the deep granulitic crust, and the brighter part refers to the intermediate to upper amphibolitic crust. MSZ denotes the Mertz shear zone and ZSZ denotes the Zélée shear zone. (For interpretation of the references to colour in this figure legend, the reader is referred to the web version of the article.)

$(2.7-2.42 \mathrm{Ga})$ domain to the east, referred to below as the Neoarchaean domain, and $(2)$ a Statherian $(1.7 \mathrm{Ga})$ domain to the west, the Paleoproterozoic domain. These domains have been interpreted as two accreted terranes separated by a major tectonic boundary, the Zélée shear zone (Monnier et al., 1996; Pelletier et al., 1999). The main tectono-metamorphic event imprint in the Paleoproterozoic domain and resulting in the craton stabilization has been dated at about $1.7 \mathrm{Ga}$ (Peucat et al., 1999a; Pelletier et al., 2002). In contrast, the Neoarchaean basement, which formed at ca. $2.8-2.7 \mathrm{Ga}$ (Nd model ages and inherited zircons), underwent a polyphase evolution with a late and major event at ca. 2.5-2.4 Ga (Ménot et al., 1999, 2005; Peucat et al., 1999b). In this domain, ages at $c a .1 .7 \mathrm{Ga}$ are considered to be either local thermal resetting related to discrete shear zones (Oliver and Fanning, 2002; SHRIMP U-Pb zircon) or a regional pervasive thermal event ( $\mathrm{Di}$ Vincenzo et al., 2007; ${ }^{40} \mathrm{Ar} /{ }^{39} \mathrm{Ar}$ laserprobe biotite). Consequently, the late tectonic and metamorphic history of the Neoarchaean domain is complex and controversial, and it appears necessary for the $P, T, t$ evolution of this domain to differentiate between the two scenarios. Thus, the Paleoproterozoic evolution needs to be re-appraised in order to estimate the spatial extent of tectonic reworking in an already cooled Neoarchaean continental crust.

In this paper we address the following questions: (1) in terms of geochronological and structural overprinting within the Neoarchaean basement, is the $1.7 \mathrm{Ga}$ resetting localized, or pervasive at a regional scale? (2) Which geodynamic context at $1.7 \mathrm{Ga}$ can explain the relationships between the Neoarchaean and Paleoproterozoic domains? We propose a reassessment of the geodynamic evolution in the light of new geochronological data, via multimethod approach, combining Th-U-Pb dating of monazite and ${ }^{40} \mathrm{Ar} /{ }^{39} \mathrm{Ar}$ dating of amphibole, biotite and muscovite.

\section{Geological setting}

The Antarctic continent can be divided into two regions: West and East Antarctica, separated by the Transantarctic Moun- tains. While West Antarctica remains active today, East Antarctica is a stable craton, amalgamated during the Ross orogeny at ca. 530 Ma (Tingey, 1991; Fitzsimons, 2000, 2003). Most of the East Antarctic shield recorded tectono-thermal activity during the Grenvillian orogeny at ca. $1 \mathrm{Ga}$ (Fitzsimons, 2000) with the noticeable exception of the Mawson continent (Fanning et al., 1995), which is considered to be devoid of any significant reworking after $1.5 \mathrm{Ga}$. The Mawson continent probably constitutes to a large portion of the unexposed East Antarctica basement, but its exact extent is rather difficult to constrain (see Fitzsimons, 2003). According to Fanning et al. (1995, 2003), it includes Terre Adélie and George Vth Land (the Terre Adélie Craton of Peucat et al., 1999a) and the Miller Range in the Central Transantarctic Mountains. Further north, it includes the South Australian's Gawler Craton and Curnamona Province. Within the Mawson continent, the composite Terre Adélie Craton (TAC) extends along the Antarctic coast between at least $136.4^{\circ} \mathrm{E}$ and $144.5^{\circ} \mathrm{E}$ and represents the easternmost area of the East Antarctic Shield (Fig. 1). The eastern boundary is marked by the prominent Mertz Shear Zone $\left(144.3^{\circ} \mathrm{E}\right.$; Talarico and Kleinschmidt, 2003), which separates the Archaean and Proterozoic basement of the TAC from the Ross-Delamerian crystalline basement including granitoids and metasediments from the Cape Webb area (Fanning et al., 2002, 2003; Di Vincenzo et al., 2007). The Ross-Delamerian rocks mark the western boundary of the Ross orogen that extends eastwards into Oates Land. The western boundary is not properly defined due to the lack of exposure and suitable geophysical information. Rocher $\mathrm{X}$ $\left(136.4^{\circ} \mathrm{E}\right)$ is the westernmost outcrop related to the TAC. Further west, outcrops in the Windmill Islands display Archaean and Proterozoic material strongly overprinted by late Mesoproterozoic events (between $1340 \mathrm{Ma}$ and $1130 \mathrm{Ma}$, Fitzsimons, 2003).

The TAC exposure is restricted to hectometre to kilometre square islands and capes scattered along the coastline and to a few nunataks, mainly in the inland area of Commonwealth Bay (Fig. 2). Extremely well-exposed polished glacial surfaces and the absence of any alteration allow for excellent field analysis in the scattered islands along the coast. Within the basement 


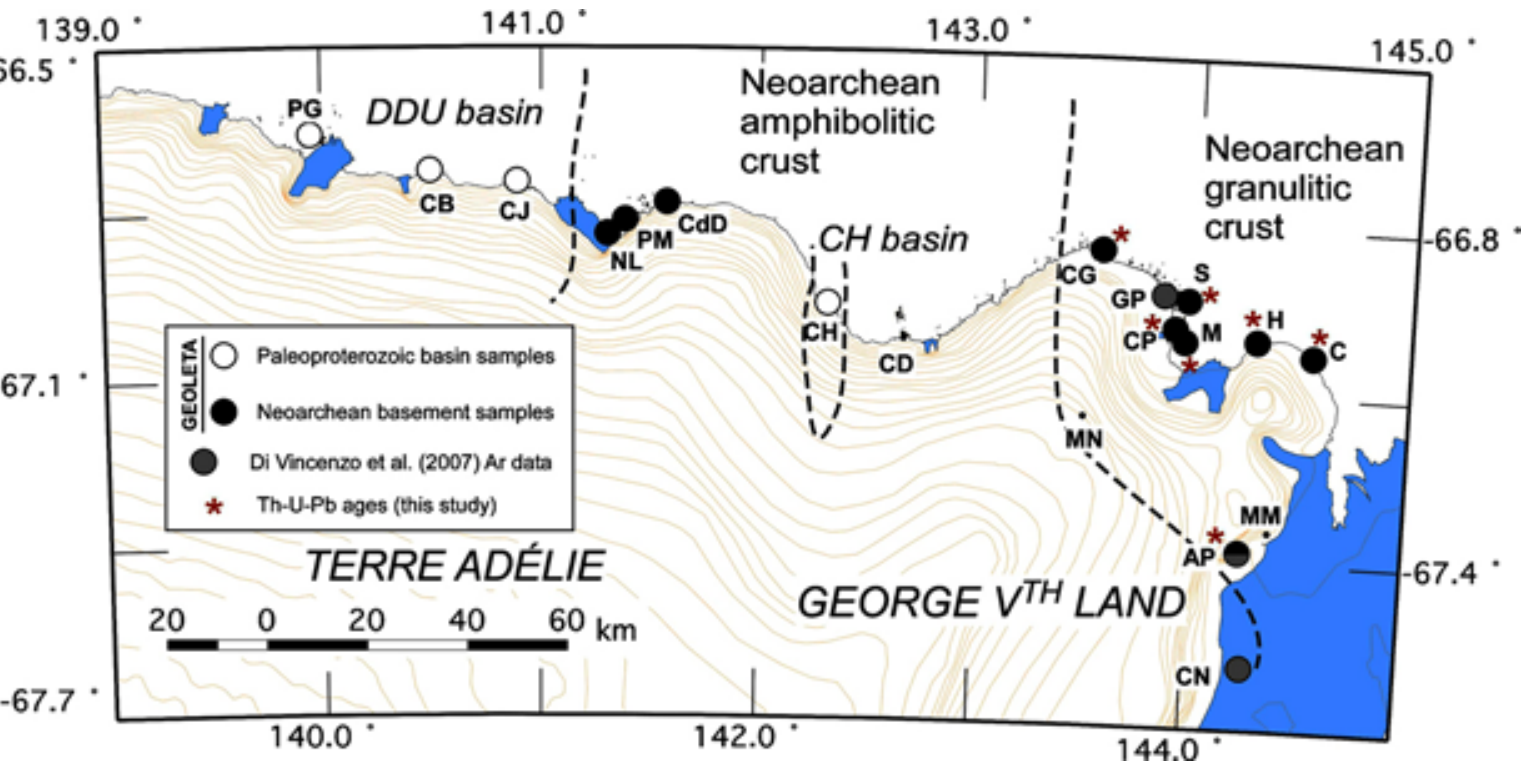

Fig. 2. Detailed samples location. Filled circles indicate the location of new ages obtained for the Neoarchaean domain, and open circles indicate those of the Paleoproterozoic domain. Grey circles indicate the location of samples dated by Di Vincenzo et al. (2007). From West to East, PG: Pointe Géologie, CB: Cap Bienvenüe, CJ: Cap Jules, NL: Nunatak Lacroix, PM: Port Martin, CdD: Cap de la Découverte, CH: Cape Hunter, CD: Cape Denison, MN: Madigan Nunatak, CG: Cape Grey, GP: Garnet Point, S: Stillwell Island, CP: Cape Pigeon, M: Moyes Archipelago, H: Hodgemann Archipelago, C: Close Island, MM: Murchinson Mounts, AP: Aurora Peak, CN: Correll Nunatak.

of the TAC, two domains are recognized differentiated by their ages and lithologies (Monnier et al., 1996; Ménot et al., 1999; Peucat et al., 1999a). (1) To the East, a complex Neoarchaean crust $(2.8-2.42 \mathrm{Ga})$ crops out from the Mertz glacier $\left(144.3^{\circ} \mathrm{E}\right)$ to the Zélée glacier $\left(141.31^{\circ} \mathrm{E}\right)$. (2) Overlaying and to the west of this domain are two Paleoproterozoic metasedimentary domain known as the Cape Hunter basin the Dumont D'Urville basin (DDU) respectively. The latter probably extends further west to Rocher Janet $\left(139.1^{\circ} \mathrm{E}\right)$, Rocher $\mathrm{X}$ and Rocher Mathieu $\left(136.4^{\circ} \mathrm{E}\right)$ (Ménot et al., 2007).

\subsection{The Neoarchaean domain}

The Neoarchaean crust can be subdivided into two metamorphic units (Ménot et al., 2005): (1) a granulite facies unit to the east, and (2) an amphibolite facies unit to the west.

(1) The deep crust is composed of both orthogneisses of felsic to mafic composition and metasediments, mainly metapelites and subordinate marbles and quartzites. This lower crust underwent a polyphase and long-lived tectonic and metamorphic evolution from granulite facies conditions (peak conditions of $T \geq 800^{\circ} \mathrm{C}$ and $P$ up to $9 \pm 1.5 \mathrm{kbar}$ ), down to amphibolite facies conditions $\left(550^{\circ} \mathrm{C}, 5 \mathrm{kbar}\right)$ for subsequent retrogression (Pelletier et al., 2001). This evolution occurred between $\sim 2.5 \mathrm{Ga}$ (initial granulitic event) and $2.42 \mathrm{Ga}$ (retrogression and related partial melting; Ménot et al., 2005 and references therein). At a regional scale, two successive metamorphic foliations are identified, observed in the granulite and amphibolite facies parageneses respectively. The granulite foliation, when preserved from transposition, is relatively flat, gently dipping to the south. The amphibolite foliation is steeper and associated with centimetre to hectometre-scale isoclinal folds and partial melting (Ménot et al., 2005). Horizontal boudinaged mafic rods and calc-silicate layers, parallel to the N140 mineral stretching lineation, indicate horizontal flow in the deep crust (Duclaux et al., 2007). These later fabrics are compatible with the dome shape structure of the deep crustal part of the Neoarchaean domain.
(2) In the intermediate to upper crust, gneissic basement is intruded by prominent monzogranodiorite plutons and laccoliths together with aluminous pink granites and mafic dikes. All granitoids display complex mingling and assimilation features (Duclaux, 2007). The syntectonic intrusion of the monzogranodiorites and the coeval amphibolite facies metamorphism was dated at ca. $2.44 \mathrm{Ga}$ by $\mathrm{U}-\mathrm{Pb}$ zircons in the Port Martin area (Monnier et al., 1996; Peucat et al., 1999b). The regional foliation trend changes from N70 to N150 approaching the Zélée shear zone to the west and the narrow Cape Hunter basin to the east (Fig. 1).

Localized centimetre to metre-scale steep shear zones are present in both crustal levels. These shear zones display a conjugate dextral and sinistral sense of shear, with a dominant dextral motion toward the East. They contain hydrated greenschist facies biotite-chlorite assemblages and act as a plumbing system for fluid circulation (Duclaux, 2007).

\subsection{The Paleoproterozoic domain}

This domain is composed of two distinct Paleoproterozoic basins (Figs. 1 and 2):

(1) To the east $\left(142.1^{\circ} \mathrm{E}\right)$, the narrow basin of Cape Hunter $(\mathrm{CH})$ between the Cape Denison and the Point Alden is characterized by the exposure of a $500-\mathrm{m}$ wide zone of phyllites pinched within the intermediate Neoarchaean crust. The contacts between the Neoarchaean basement and the basin have not been identified in the field due to ice cover. The Cape Hunter sediments are mainly pelitic with a slight volcanic component dated by a SHRIMP zircon age at $1765 \pm 8 \mathrm{Ma}$ (Oliver and Fanning, 1997). Subsequent recrystallization occurred under greenschist facies conditions (350-500 ${ }^{\circ} \mathrm{C}$ at $\left.4-5 \mathrm{kbar}\right)$ (Oliver and Fanning, 1997). These phyllites contain a penetrative vertical foliation associated with upright folds and associated vertical axial planes (Ménot et al., 2005). 

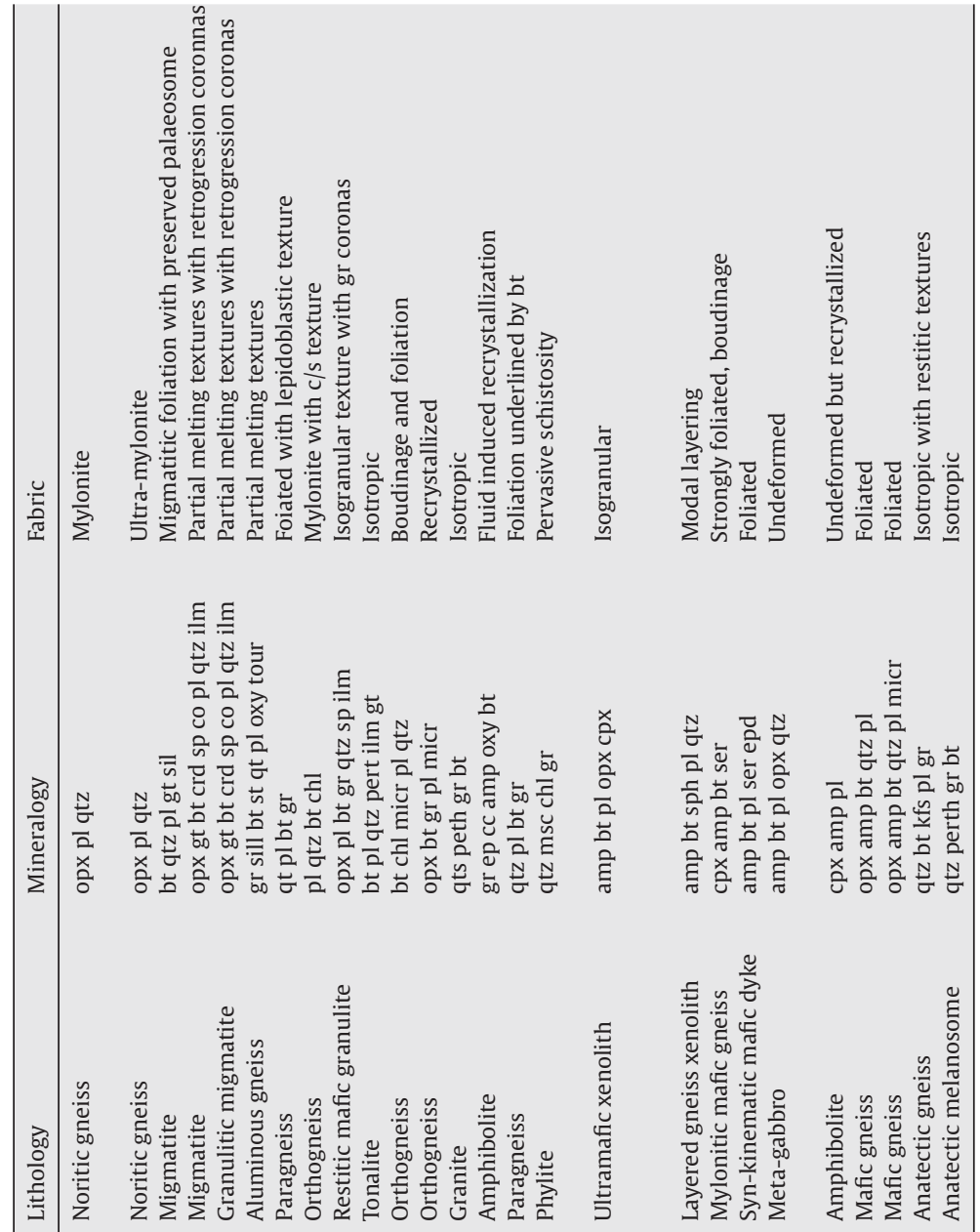

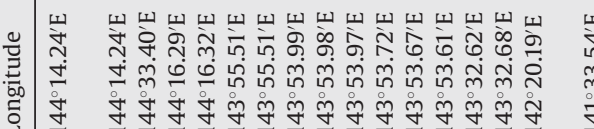

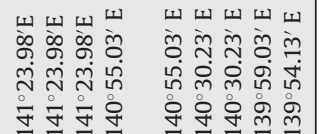

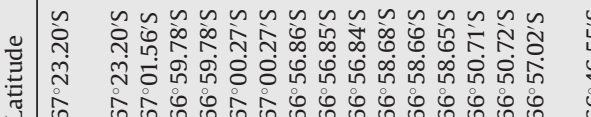

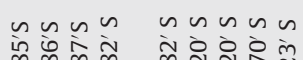

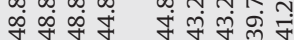

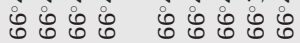

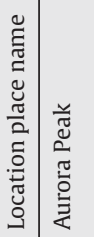

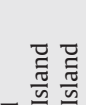

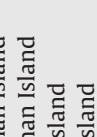

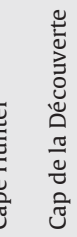

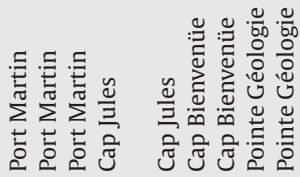

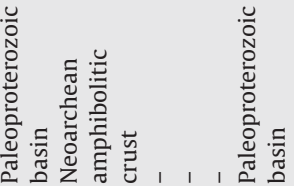

₹

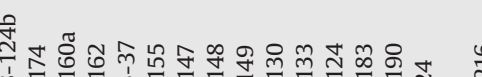

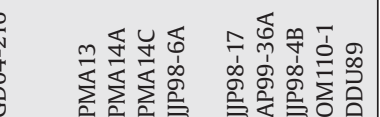


Table 2

Monazites ages, chemical and textural characteristics.

\begin{tabular}{|c|c|c|c|c|c|c|c|c|c|c|c|}
\hline Analyse & Location & $n$ & $\begin{array}{l}\text { Associated } \\
\text { fabric }\end{array}$ & $\mathrm{ThO}_{2}$ & $\mathrm{UO}_{2}$ & $\mathrm{PbO}$ & Age (Ma) & $\begin{array}{l}2 \sigma \text { error } \\
(\mathrm{Ma})\end{array}$ & $\mathrm{ThO}_{2}{ }^{*}$ & $\mathrm{UO}_{2}{ }^{*}$ & $\mathrm{PbO} / \mathrm{ThO}_{2}{ }^{*}$ \\
\hline & Aurora Peak & & & & & & & & & & \\
\hline & & 8 & mnz in foliation & $1.67-8.83$ & $0.05-0.29$ & $0.13-0.67$ & 1619 & \pm 48 & MSWD $=$ & & \\
\hline & & 4 & mnz in foliation & $2.52-17.80$ & $0.15-0.21$ & $0.27-1.48$ & 1995 & \pm 52 & MSWD $>$ & & \\
\hline \multicolumn{12}{|l|}{ Detailed analyses } \\
\hline RPM98-124B & Aurora Peak & & & & & & & & & & \\
\hline 1 & & & & 8.8301 & 0.1217 & 0.6680 & 1646.80 & \pm 44.63 & 9.2762 & 2.5310 & 0.0720 \\
\hline 2 & & & & 17.8033 & 0.1548 & 1.4752 & 1826.71 & \pm 32.27 & 18.3819 & 4.9186 & 0.0803 \\
\hline 3 & & & & 6.9581 & 0.0543 & 0.5340 & 1703.11 & \pm 54.32 & 7.1583 & 1.9414 & 0.0746 \\
\hline 4 & & & & 1.6671 & 0.0731 & 0.1255 & 1493.45 & \pm 148.32 & 1.9307 & 0.5352 & 0.0650 \\
\hline RPM98-119 & Aurora Peak & & & & & & & & & & \\
\hline 1 & & & & 3.8344 & 0.1334 & 0.3078 & 1630.02 & \pm 76.37 & 4.3225 & 1.1816 & 0.0712 \\
\hline 2 & & & & 4.0629 & 0.2895 & 0.3454 & 1550.67 & \pm 65.38 & 5.1131 & 1.4094 & 0.0676 \\
\hline 3 & & & & 3.6025 & 0.1281 & 0.2873 & 1616.29 & \pm 80.64 & 4.0703 & 1.1142 & 0.0706 \\
\hline 4 & & & & 6.0942 & 0.2105 & 0.5932 & 1954.12 & \pm 57.91 & 6.8924 & 1.8180 & 0.0861 \\
\hline 5 & & & & 2.5899 & 0.2560 & 0.2504 & 1627.88 & \pm 81.63 & 3.5260 & 0.9643 & 0.0710 \\
\hline 6 & & & & 2.3438 & 0.0784 & 0.1769 & 1544.11 & \pm 114.97 & 2.6281 & 0.7248 & 0.0673 \\
\hline 7 & & & & 2.6128 & 0.1846 & 0.3255 & 2204.51 & \pm 99.72 & 3.3342 & 0.8534 & 0.0976 \\
\hline \multirow[t]{4}{*}{8} & & & & 2.5162 & 0.1575 & 0.2740 & 1995.77 & \pm 103.15 & 3.1161 & 0.8181 & 0.0879 \\
\hline & Fletcher C & & & & & & & & & & \\
\hline & & 6 & $\begin{array}{l}\text { mnz in foliation } \\
\text { with biotite }\end{array}$ & $1.90-4.55$ & $0.15-0.22$ & $0.21-0.38$ & 1712 & \pm 34 & $M S W D=$ & & \\
\hline & & 10 & mnz in foliation & $1.99-4.04$ & $0.15-0.27$ & $0.24-0.41$ & 1897 & \pm 28 & $M S W D=$ & & \\
\hline \multicolumn{12}{|l|}{ Detailed analyses } \\
\hline GD04-190 & Fletcher C & & & & & & & & & & \\
\hline 1 & & & & 3.3880 & 0.1495 & 0.2980 & 1727.22 & \pm 41.50 & 3.9406 & 1.0662 & 0.0756 \\
\hline 2 & & & & 3.1790 & 0.1565 & 0.2850 & 1732.41 & \pm 42.88 & 3.7576 & 1.0161 & 0.0758 \\
\hline 3 & & & & 2.0030 & 0.2720 & 0.2450 & 1849.29 & \pm 47.76 & 3.0216 & 0.8069 & 0.0811 \\
\hline 4 & & & & 2.1240 & 0.2468 & 0.2530 & 1888.05 & \pm 48.60 & 3.0525 & 0.8115 & 0.0829 \\
\hline 5 & & & & 2.0460 & 0.2172 & 0.2510 & 1985.40 & \pm 52.72 & 2.8724 & 0.7551 & 0.0874 \\
\hline 6 & & & & 1.8970 & 0.2219 & 0.2120 & 1779.25 & \pm 51.12 & 2.7216 & 0.7324 & 0.0779 \\
\hline 7 & & & & 1.9940 & 0.2659 & 0.2420 & 1846.54 & \pm 47.76 & 2.9893 & 0.7985 & 0.0810 \\
\hline 8 & & & & 1.9780 & 0.1814 & 0.2080 & 1789.63 & \pm 53.48 & 2.6530 & 0.7131 & 0.0784 \\
\hline 9 & & & & 3.9010 & 0.1879 & 0.4080 & 2004.47 & \pm 41.12 & 4.6173 & 1.2109 & 0.0884 \\
\hline 10 & & & & 4.0350 & 0.1503 & 0.3900 & 1925.43 & \pm 40.82 & 4.6028 & 1.2181 & 0.0847 \\
\hline 11 & & & & 3.2360 & 0.2129 & 0.3330 & 1878.28 & \pm 42.19 & 4.0362 & 1.0741 & 0.0825 \\
\hline 12 & & & & 3.3560 & 0.2197 & 0.3190 & 1747.36 & \pm 39.37 & 4.1698 & 1.1258 & 0.0765 \\
\hline 13 & & & & 3.5480 & 0.2417 & 0.3620 & 1851.73 & \pm 38.99 & 4.4535 & 1.1887 & 0.0813 \\
\hline 14 & & & & 3.8790 & 0.1890 & 0.3770 & 1870.19 & \pm 39.29 & 4.5885 & 1.2221 & 0.0822 \\
\hline 15 & & & & 4.5500 & 0.2216 & 0.3780 & 1615.68 & \pm 31.97 & 5.3593 & 1.4673 & 0.0705 \\
\hline \multirow[t]{4}{*}{16} & & & & 3.8620 & 0.1993 & 0.3820 & 1884.84 & \pm 39.06 & 4.6117 & 1.2262 & 0.0828 \\
\hline & Cape Pigeon & & & & & & & & & & \\
\hline & & 12 & mnz in foliation & $1.63-6.78$ & $0.07-0.15$ & $0.14-0.52$ & 1697 & \pm 44 & $M S W D=$ & & \\
\hline & & 4 & mnz in feldpar & $3.17-6.20$ & $0.10-0.16$ & $0.30-0.57$ & 1869 & \pm 70 & $M S W D=$ & & \\
\hline \multicolumn{12}{|l|}{ Detailed analyses } \\
\hline GD04-130 & Cape Pigeon & & & & & & & & & & \\
\hline 1 & & & & 4.0042 & 0.1229 & 0.3572 & 1822.89 & \pm 77.90 & 4.4632 & 1.1949 & 0.0800 \\
\hline 2 & & & & 3.4761 & 0.0954 & 0.2910 & 1734.70 & \pm 86.52 & 3.8291 & 1.0351 & 0.0760 \\
\hline 3 & & & & 3.1666 & 0.0969 & 0.3018 & 1939.77 & \pm 95.06 & 3.5335 & 0.9336 & 0.0854 \\
\hline 4 & & & & 3.8075 & 0.0927 & 0.3189 & 1752.70 & \pm 82.17 & 4.1511 & 1.1199 & 0.0768 \\
\hline 5 & & & & 4.0839 & 0.0981 & 0.3418 & 1753.31 & \pm 77.67 & 4.4476 & 1.1998 & 0.0769 \\
\hline 6 & & & & 1.6330 & 0.0653 & 0.1422 & 1732.41 & \pm 151.29 & 1.8744 & 0.5069 & 0.0759 \\
\hline 7 & & & & 6.5167 & 0.1465 & 0.5332 & 1724.62 & \pm 54.17 & 7.0581 & 1.9100 & 0.0755 \\
\hline 8 & & & & 6.7836 & 0.1267 & 0.5206 & 1642.99 & \pm 53.48 & 7.2479 & 1.9784 & 0.0718 \\
\hline 9 & & & & 5.6803 & 0.1226 & 0.4632 & 1724.01 & \pm 60.73 & 6.1334 & 1.6599 & 0.0755 \\
\hline 10 & & & & 6.1966 & 0.1250 & 0.5693 & 1938.10 & \pm 59.89 & 6.6695 & 1.7623 & 0.0854 \\
\hline 11 & & & & 5.8124 & 0.1620 & 0.5066 & 1799.39 & \pm 59.43 & 6.4161 & 1.7222 & 0.0790 \\
\hline 12 & & & & 4.0882 & 0.1085 & 0.3268 & 1665.57 & \pm 75.76 & 4.4866 & 1.2218 & 0.0728 \\
\hline GD04-133 & Cape Pigeon & & & & & & & & & & \\
\hline 1 & & & & 4.0293 & 0.1808 & 0.3353 & 1636.28 & \pm 78.43 & 4.6911 & 1.2816 & 0.0715 \\
\hline 2 & & & & 2.9687 & 0.1553 & 0.2615 & 1688.92 & \pm 98.88 & 3.5405 & 0.9619 & 0.0739 \\
\hline 3 & & & & 2.8583 & 0.1290 & 0.2387 & 1640.40 & \pm 103.84 & 3.3309 & 0.9096 & 0.0717 \\
\hline \multirow[t]{5}{*}{4} & & & & 3.3470 & 0.1244 & 0.2303 & 1398.54 & \pm 89.80 & 3.7915 & 1.0610 & 0.0607 \\
\hline & Stilwell Island & & & & & & & & & & \\
\hline & & 6 & $\begin{array}{l}\text { in } \\
\text { quartz+feldspar } \\
\text { foliation }\end{array}$ & $3.26-11.95$ & $0.07-0.31$ & $0.41-1.44$ & 2468 & \pm 44 & MSWD = & & \\
\hline & & 9 & mnz in garnet & $3.49-12.71$ & $0.08-0.23$ & $0.48-1.52$ & 2586 & \pm 38 & $M S W D=$ & & \\
\hline & & 1 & mnz in garnet & & & & 3386 & \pm 84 & & & relictual? \\
\hline \multicolumn{12}{|l|}{ Detailed analyses } \\
\hline GD04-124 & Stilwell Island & & & & & & & & & & \\
\hline 1 & & & & 11.9451 & 0.2099 & 1.4385 & 2514.72 & \pm 46.39 & 12.8004 & 3.1418 & 0.1124 \\
\hline 2 & & & & 10.2258 & 0.1919 & 1.2695 & 2575.30 & \pm 50.89 & 11.0143 & 2.6800 & 0.1153 \\
\hline
\end{tabular}


Table 2 (Continued)

\begin{tabular}{|c|c|c|c|c|c|c|c|c|c|c|c|}
\hline Analyse & Location & $n$ & $\begin{array}{l}\text { Associated } \\
\text { fabric }\end{array}$ & $\mathrm{ThO}_{2}$ & $\mathrm{UO}_{2}$ & $\mathrm{PbO}$ & Age (Ma) & $\begin{array}{l}2 \sigma \text { error } \\
(\mathrm{Ma})\end{array}$ & $\mathrm{ThO}_{2}{ }^{*}$ & $\mathrm{UO}_{2}^{*}$ & $\mathrm{PbO} / \mathrm{ThO}_{2}{ }^{*}$ \\
\hline 3 & & & & 10.7233 & 0.1850 & 1.3452 & 2613.75 & \pm 50.20 & 11.4878 & 2.7795 & 0.1171 \\
\hline 4 & & & & 10.1032 & 0.1726 & 1.1618 & 2414.02 & \pm 49.36 & 10.7967 & 2.6873 & 0.1076 \\
\hline 5 & & & & 10.6252 & 0.1555 & 1.2869 & 2554.09 & \pm 50.20 & 11.2624 & 2.7487 & 0.1143 \\
\hline 6 & & & & 10.8524 & 0.1722 & 1.3491 & 2604.75 & \pm 50.05 & 11.5632 & 2.8014 & 0.1167 \\
\hline 7 & & & & 8.2189 & 0.3055 & 1.0211 & 2425.16 & \pm 51.80 & 9.4481 & 2.3485 & 0.1081 \\
\hline 8 & & & & 3.4856 & 0.1420 & 0.4777 & 2619.40 & \pm 92.77 & 4.0727 & 0.9848 & 0.1173 \\
\hline 9 & & & & 3.5892 & 0.1115 & 0.4799 & 2642.75 & \pm 94.99 & 4.0520 & 0.9763 & 0.1184 \\
\hline 10 & & & & 3.2622 & 0.1168 & 0.4115 & 2469.56 & \pm 97.50 & 3.7349 & 0.9227 & 0.1102 \\
\hline 11 & & & & 4.5789 & 0.1233 & 0.7847 & 3336.87 & \pm 84.46 & 5.1553 & 1.1030 & 0.1522 \\
\hline 12 & & & & 9.1125 & 0.0814 & 1.0434 & 2474.59 & \pm 55.24 & 9.4423 & 2.3305 & 0.1105 \\
\hline 13 & & & & 9.3972 & 0.0747 & 1.0890 & 2511.37 & \pm 55.08 & 9.7013 & 2.3820 & 0.1123 \\
\hline 14 & & & & 8.4356 & 0.0791 & 1.0000 & 2551.50 & \pm 58.67 & 8.7598 & 2.1386 & 0.1142 \\
\hline 15 & & & & 8.9397 & 0.2331 & 1.1739 & 2643.51 & \pm 53.71 & 9.9074 & 2.3868 & 0.1185 \\
\hline \multirow[t]{4}{*}{16} & & & & 12.7102 & 0.1627 & 1.5205 & 2541.73 & \pm 46.16 & 13.3755 & 3.2702 & 0.1137 \\
\hline & Watt Bay & & & & & & & & & & \\
\hline & & 4 & mnz in foliation & $1.23-2.65$ & $0.12-0.38$ & $0.13-0.28$ & 1755 & \pm 54 & $M S W D=$ & & \\
\hline & & 2 & mnz in foliation & $1.41-1.44$ & $0.19-1.28$ & $0.19-0.23$ & 2094 & \pm 180 & $M S W D=$ & & relictual? \\
\hline \multicolumn{12}{|c|}{ Detailed analyses } \\
\hline GD04-155 & Watt Bay & & & & & & & & & & \\
\hline 1 & & & & 1.2328 & 0.1231 & 0.1277 & 1729.81 & \pm 166.78 & 1.6879 & 0.4567 & 0.0757 \\
\hline 2 & & & & 2.1331 & 0.3332 & 0.2579 & 1751.63 & \pm 88.04 & 3.3673 & 0.9090 & 0.0766 \\
\hline 3 & & & & 1.4077 & 0.1910 & 0.1946 & 2062.15 & \pm 138.70 & 2.1408 & 0.5578 & 0.0909 \\
\hline 4 & & & & 1.4378 & 0.2767 & 0.2340 & 2116.32 & \pm 118.10 & 2.5066 & 0.6489 & 0.0934 \\
\hline RPM03-37 & Watt Bay & & & & & & & & & & \\
\hline 1 & & & & 2.6470 & 0.2625 & 0.2640 & 1673.81 & \pm 42.11 & 3.6114 & 0.9829 & 0.0731 \\
\hline \multirow[t]{4}{*}{2} & & & & 2.0730 & 0.3789 & 0.2790 & 1826.40 & \pm 38.83 & 3.4882 & 0.9340 & 0.0800 \\
\hline & Hodgeman Arch. & & & & & & & & & & \\
\hline & & 8 & $\begin{array}{l}\text { mnz in garnet } \\
\text { and feldspar }\end{array}$ & $2.84-5.80$ & $0.10-0.30$ & $0.31-0.71$ & 2282 & $\pm \mathbf{4 0}$ & MSWD = & & \\
\hline & & 14 & $\begin{array}{l}\text { mnz in garnet } \\
\text { and feldspar }\end{array}$ & $3.12-16.93$ & $0.07-0.44$ & $0.34-1.99$ & 2477 & $\pm \mathbf{2 2}$ & $M S W D=$ & & \\
\hline \multicolumn{12}{|c|}{ Detailed analyses } \\
\hline GD04-162 & Hodgeman Arch. & & & & & & & & & & \\
\hline 1 & & & & 7.0360 & 0.2548 & 0.8670 & 2414.47 & \pm 35.93 & 8.0597 & 2.0063 & 0.1076 \\
\hline 2 & & & & 6.7390 & 0.1559 & 0.8170 & 2482.53 & \pm 39.52 & 7.3714 & 1.8176 & 0.1108 \\
\hline 3 & & & & 7.2470 & 0.2870 & 0.9180 & 2449.42 & \pm 35.48 & 8.4056 & 2.0824 & 0.1092 \\
\hline 4 & & & & 16.9310 & 0.2798 & 1.9890 & 2466.81 & \pm 27.85 & 18.0633 & 4.4634 & 0.1101 \\
\hline 5 & & & & 5.4960 & 0.2944 & 0.7100 & 2390.06 & \pm 37.77 & 6.6746 & 1.6672 & 0.1064 \\
\hline 6 & & & & 8.4810 & 0.2465 & 1.0350 & 2448.96 & \pm 34.26 & 9.4760 & 2.3475 & 0.1092 \\
\hline 7 & & & & 5.3190 & 0.2971 & 0.6540 & 2271.19 & \pm 36.77 & 6.4899 & 1.6468 & 0.1008 \\
\hline 8 & & & & 8.0780 & 0.4355 & 1.1350 & 2572.86 & \pm 33.11 & 9.8667 & 2.4024 & 0.1150 \\
\hline 9 & & & & 7.5230 & 0.3757 & 0.9310 & 2324.30 & \pm 32.12 & 9.0139 & 2.2713 & 0.1033 \\
\hline 10 & & & & 7.5590 & 0.4291 & 1.0740 & 2576.52 & \pm 33.72 & 9.3224 & 2.2687 & 0.1152 \\
\hline GD04-160A & Hodgeman Arch. & & & & & & & & & & \\
\hline 1 & & & & 2.8448 & 0.0508 & 0.3088 & 2282.33 & \pm 113.75 & 3.0453 & 0.7714 & 0.1014 \\
\hline 2 & & & & 4.0971 & 0.0781 & 0.4507 & 2301.41 & \pm 86.14 & 4.4060 & 1.1133 & 0.1023 \\
\hline 3 & & & & 4.0478 & 0.0732 & 0.4684 & 2419.66 & \pm 88.73 & 4.3423 & 1.0800 & 0.1079 \\
\hline 4 & & & & 3.2890 & 0.0724 & 0.3364 & 2129.75 & \pm 97.96 & 3.5693 & 0.9218 & 0.0942 \\
\hline 5 & & & & 3.1181 & 0.0835 & 0.3765 & 2443.62 & \pm 104.06 & 3.4549 & 0.8565 & 0.1090 \\
\hline 6 & & & & 4.3900 & 0.0799 & 0.5288 & 2509.84 & \pm 84.76 & 4.7153 & 1.1581 & 0.1121 \\
\hline 7 & & & & 5.1275 & 0.1036 & 0.5514 & 2244.80 & \pm 73.01 & 5.5346 & 1.4088 & 0.0996 \\
\hline 8 & & & & 5.1962 & 0.1494 & 0.6187 & 2396.93 & \pm 71.33 & 5.7949 & 1.4459 & 0.1068 \\
\hline 9 & & & & 5.7969 & 0.0964 & 0.6158 & 2246.32 & \pm 67.52 & 6.1757 & 1.5717 & 0.0997 \\
\hline 10 & & & & 5.6919 & 0.1506 & 0.7563 & 2668.38 & \pm 70.88 & 6.3193 & 1.5167 & 0.1197 \\
\hline 11 & & & & 5.8448 & 0.1391 & 0.6963 & 2437.67 & \pm 67.52 & 6.4056 & 1.5893 & 0.1087 \\
\hline \multirow[t]{5}{*}{12} & & & & 6.0775 & 0.2165 & 0.7488 & 2418.75 & \pm 62.94 & 6.9477 & 1.7285 & 0.1078 \\
\hline & C Island & & & & & & & & & & \\
\hline & & 6 & mnz in foliation & $3.37-13.27$ & $0.18-0.35$ & $0.21-1.08$ & 1696 & \pm 44 & $M S W D=$ & & \\
\hline & & 14 & $\begin{array}{l}\text { mnz in garnet } \\
\text { and feldspar }\end{array}$ & $1.84-8.82$ & $0.15-0.50$ & $0.45-1.14$ & 2629 & $\pm \mathbf{2 2}$ & $M S W D=$ & & \\
\hline & & 11 & $\begin{array}{l}\text { mnz in garnet } \\
\text { and feldspar }\end{array}$ & $5.41-8.84$ & $0.14-0.49$ & $0.70-1.02$ & 2433 & \pm 34 & $M S W D=$ & & \\
\hline \multicolumn{12}{|c|}{ Detailed analyses } \\
\hline GD04-147 & C Island & & & & & & & & & & \\
\hline 1 & & & & 8.3729 & 0.2210 & 0.6663 & 1659.16 & \pm 48.83 & 9.1838 & 2.5027 & 0.0726 \\
\hline 2 & & & & 3.5182 & 0.1783 & 0.3109 & 1702.04 & \pm 86.06 & 4.1752 & 1.1328 & 0.0745 \\
\hline 3 & & & & 3.3708 & 0.1882 & 0.3112 & 1747.06 & \pm 89.26 & 4.0678 & 1.0983 & 0.0765 \\
\hline 4 & & & & 3.7710 & 0.2161 & 0.3161 & 1589.89 & \pm 79.42 & 4.5583 & 1.2514 & 0.0693 \\
\hline 5 & & & & 13.2664 & 0.3457 & 1.0805 & 1697.77 & \pm 36.93 & 14.5400 & 3.9461 & 0.0743 \\
\hline 6 & & & & 10.5642 & 0.2807 & 0.8854 & 1741.41 & \pm 43.18 & 11.6035 & 3.1344 & 0.0763 \\
\hline
\end{tabular}


Table 2 (Continued)

\begin{tabular}{|c|c|c|c|c|c|c|c|c|c|c|c|}
\hline Analyse & Location & $n$ & $\begin{array}{l}\text { Associated } \\
\text { fabric }\end{array}$ & $\mathrm{ThO}_{2}$ & $\mathrm{UO}_{2}$ & $\mathrm{PbO}$ & Age (Ma) & $\begin{array}{l}2 \sigma \text { error } \\
(\mathrm{Ma})\end{array}$ & $\mathrm{ThO}_{2}{ }^{*}$ & $\mathrm{UO}_{2} *$ & $\mathrm{PbO} / \mathrm{ThO}_{2}{ }^{*}$ \\
\hline \multicolumn{12}{|c|}{ Detailed analyses } \\
\hline GD04-148 & C Island & & & & & & & & & & \\
\hline 1 & & & & 6.3650 & 0.2047 & 0.8620 & 2663.80 & \pm 41.20 & 7.2172 & 1.7336 & 0.1194 \\
\hline 2 & & & & 6.8540 & 0.1514 & 0.7810 & 2353.44 & \pm 37.46 & 7.4573 & 1.8715 & 0.1047 \\
\hline 3 & & & & 6.7090 & 0.1849 & 0.9090 & 2705.76 & \pm 41.50 & 7.4837 & 1.7861 & 0.1215 \\
\hline 4 & & & & 6.6090 & 0.1595 & 0.8470 & 2602.77 & \pm 41.05 & 7.2671 & 1.7613 & 0.1166 \\
\hline 5 & & & & 4.2840 & 0.3421 & 0.6790 & 2657.09 & \pm 42.34 & 5.7062 & 1.3725 & 0.1190 \\
\hline 6 & & & & 7.0770 & 0.2104 & 0.9110 & 2565.08 & \pm 38.15 & 7.9402 & 1.9351 & 0.1147 \\
\hline 7 & & & & 6.7050 & 0.2004 & 0.8270 & 2466.20 & \pm 37.92 & 7.5157 & 1.8575 & 0.1100 \\
\hline 8 & & & & 2.3710 & 0.4531 & 0.5460 & 2825.09 & \pm 45.39 & 4.3030 & 1.0091 & 0.1269 \\
\hline 9 & & & & 8.0040 & 0.1915 & 1.0270 & 2607.50 & \pm 37.61 & 8.7949 & 2.1301 & 0.1168 \\
\hline 10 & & & & 3.2090 & 0.2151 & 0.4600 & 2521.90 & \pm 50.74 & 4.0859 & 1.0022 & 0.1126 \\
\hline 11 & & & & 8.7060 & 0.2055 & 1.1130 & 2601.70 & \pm 36.16 & 9.5537 & 2.3158 & 0.1165 \\
\hline 12 & & & & 8.8220 & 0.1917 & 1.1350 & 2633.59 & \pm 36.62 & 9.6165 & 2.3201 & 0.1180 \\
\hline 13 & & & & 6.8210 & 0.2144 & 0.8780 & 2550.74 & \pm 38.60 & 7.6988 & 1.8802 & 0.1140 \\
\hline 14 & & & & 1.8400 & 0.5004 & 0.4540 & 2605.82 & \pm 43.95 & 3.9030 & 0.9466 & 0.1163 \\
\hline \multicolumn{12}{|c|}{ Detailed analyses } \\
\hline GD04-149 & C Island & & & & & & & & & & \\
\hline 1 & & & & 8.2773 & 0.1549 & 0.9616 & 2423.32 & \pm 61.26 & 8.9005 & 2.2126 & 0.1080 \\
\hline 2 & & & & 5.9703 & 0.2890 & 0.8192 & 2561.11 & \pm 68.28 & 7.1552 & 1.7451 & 0.1145 \\
\hline 3 & & & & 8.6019 & 0.1364 & 1.0042 & 2458.27 & \pm 60.27 & 9.1534 & 2.2645 & 0.1097 \\
\hline 4 & & & & 6.3944 & 0.2235 & 0.8115 & 2489.70 & \pm 68.13 & 7.3018 & 1.7988 & 0.1111 \\
\hline 5 & & & & 5.4092 & 0.4937 & 0.8843 & 2648.39 & \pm 63.78 & 7.4589 & 1.7966 & 0.1186 \\
\hline 6 & & & & 5.4503 & 0.2431 & 0.7026 & 2450.33 & \pm 72.33 & 6.4315 & 1.5932 & 0.1092 \\
\hline 7 & & & & 7.4841 & 0.4676 & 0.9603 & 2315.60 & \pm 54.24 & 9.3375 & 2.3558 & 0.1028 \\
\hline 8 & & & & 7.9919 & 0.1813 & 0.9179 & 2365.95 & \pm 60.50 & 8.7154 & 2.1835 & 0.1053 \\
\hline 9 & & & & 8.4724 & 0.1779 & 1.0077 & 2457.05 & \pm 59.74 & 9.1914 & 2.2743 & 0.1096 \\
\hline 10 & & & & 8.8380 & 0.1654 & 1.0164 & 2400.74 & \pm 58.21 & 9.5013 & 2.3692 & 0.1070 \\
\hline 11 & & & & 6.5900 & 0.2143 & 0.8617 & 2577.90 & \pm 68.28 & 7.4711 & 1.8174 & 0.1153 \\
\hline
\end{tabular}

(2) To the west of the Neoarchaean domain, the Dumont D'Urville basin (DDU) is exposed in the Cap Jules $\left(140.5^{\circ} \mathrm{E}\right)$, the Cap Bienvenüe $\left(140.3^{\circ} \mathrm{E}\right)$, and the Pointe Géologie Archipelago $\left(139.8-140^{\circ} \mathrm{E}\right)$. The metasedimentary sequence in these three areas are dominated by metapelites including subordinate metagraywackes and dismembered layers of metafelsites and calc-silicates (Monnier et al., 1996). These lithologies are affected by extensive partial melting and intruded by synkinematic granitic and mafic dykes, and locally by synkinematic gabbroic plutons (Pelletier et al., 2002). Metapelites are equilibrated under HT-LP metamorphic conditions, with peak conditions of $650-750^{\circ} \mathrm{C}$ and $4-6$ kbar (Monnier, 1995; Pelletier et al., 2002). The evolution of the DDU basin is bracketed by the $1.72 \mathrm{Ga}$ minimum sediment deposition age, and the $1.69 \mathrm{Ga}$ peak of metamorphism (Peucat et al., 1999a). Regional foliation trajectories reveal two main structure types, both associated with migmatization: (1) large dome-shaped structures with a composite foliation that ranges from flat-lying to gently dipping, and (2) kilometre-scale vertical shear zones (Pelletier et al., 2002; Gapais et al., 2008). These authors proposed that the relative volume of the vertical shear zones widened at the expense of the domes. This coincides with an increasing dextral strike slip component when approaching the Neoarchaean domain, which acted as a rigid block (Fig. 1 in Pelletier et al., 2002).

\section{Analytical settings}

\subsection{Electron microprobe dating of monazite}

Monazite from 13 samples (described in Table 1) have been dated with a Cameca Camebax and Cameca SX100 electron microprobes using the method described in Goncalves et al. (2004).
The detailed analytical protocols are summarized in Appendix A. Analyses were undertaken using an accelerating voltage of $15 \mathrm{kV}$ and beam current of $150 \mathrm{nA}$ and a electron beam radius of around 3-4 $\mu \mathrm{m}$. Ages have been calculated following the statistical Th-U-Pb method of Montel et al. (1996) and are summarized in Table 2. The in situ analyses have been modelled according to a least-squares fit equation for a Gaussian distribution (Montel et al., 1996). The Chi square test (Montel et al., 1996) and the Mean Squared Weighted Deviation (MSWD) (Wendt and Carl, 1991) are used as "goodness of fit tests" for validity of the model. The SEM (Fig. 3B) data was collected at the CSIRO X-Ray laboratory in Kensington (WA) using a Philips (FEI) XL40 controlled pressure SEM fitted with an EDAX energy dispersive X-ray spectrometer and a Robinson Back Scattered Electron (BSE) detector. The SEM was operated in controlled pressure mode with a chamber pressure between 0.1 mbar and 0.5 mbar and an accelerating voltage of $30 \mathrm{kV}$.

\section{2. ${ }^{39} \mathrm{Ar}-{ }^{40}$ Ar analytical procedure}

Single grains of biotite (14 samples), muscovite ( 2 samples) and amphibole ( 3 samples) were handpicked under a binocular microscope from $125 \mu \mathrm{m}$ to $250 \mu \mathrm{m}$ mineral fractions, after using magnetic and heavy liquid separation methods. Samples were wrapped in aluminium foil to form small packets $(11 \mathrm{~mm} \times 11 \mathrm{~mm})$ that were stacked up to form a pile within which standards were inserted every 11-12 samples. The irradiation standard was amphibole Hb3gr (1071.7 $\pm 5.4 \mathrm{Ma}$; Turner et al., 1971; Roddick, 1983; Jourdan et al., 2006). The irradiation was performed at the McMaster reactor (Hamilton, Canada) and lasted $120 \mathrm{~h}$ (5C position, total fluence of $9 \times 10^{18} \mathrm{n} \mathrm{cm}^{-2}$ ). The sample and standards arrangement within the irradiation allowed us to monitor the flux gradient with a precision of $\pm 0.2 \%$. 

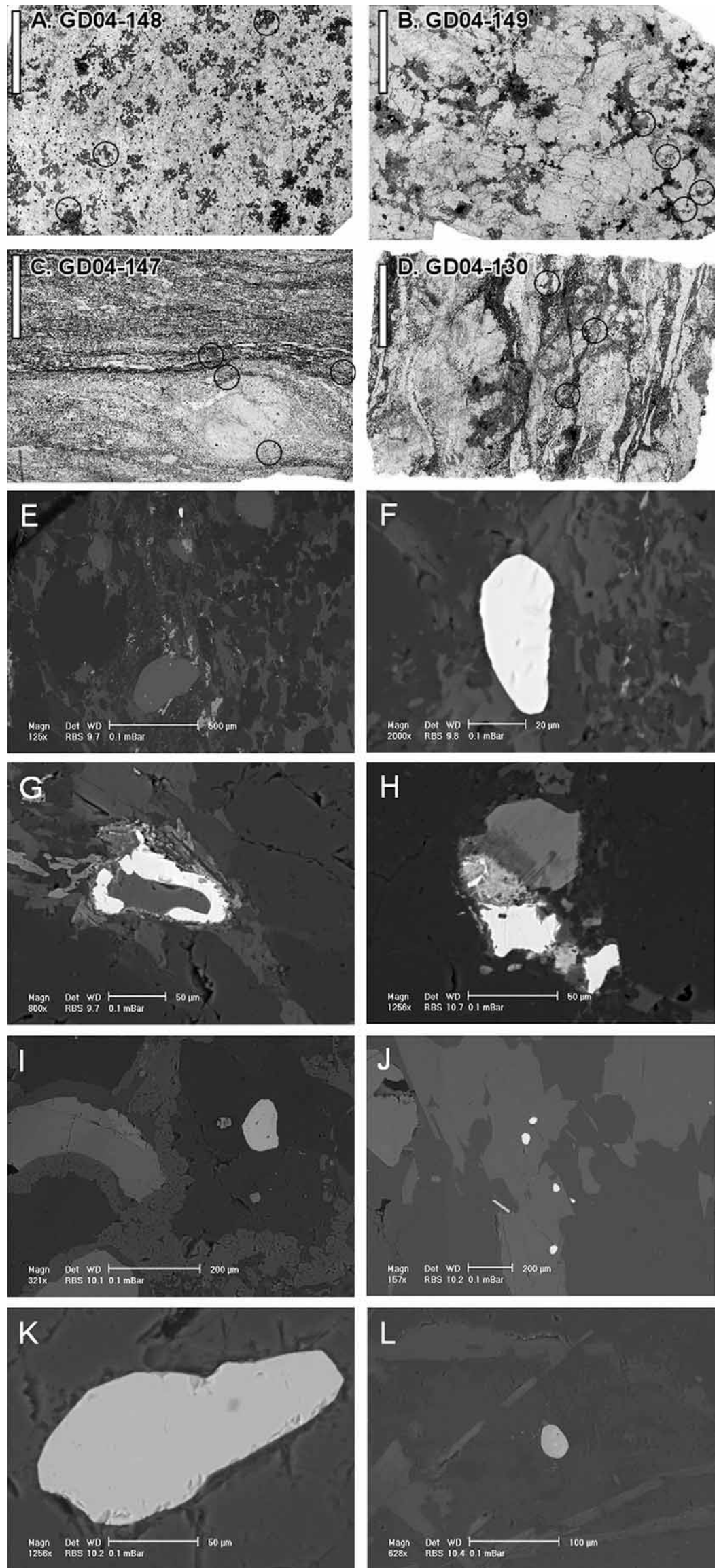
The step-heating experiments conducted on single grains have been described by Ruffet et al. (1991, 1995) and Rolland et al. (2008). $\mathrm{CO}_{2}$-laser step-heating experiments were analysed on Map215 ${ }^{\circledR}$ and VG3600 ${ }^{\circledR}$ mass spectrometers. Blanks were performed routinely every three steps, and subtracted from subsequent sample gas fractions. Isotopic measurements were corrected for $\mathrm{K}, \mathrm{Ca}$ and $\mathrm{Cl}$ isotopic interferences and mass discrimination. It is commonly acknowledged that a plateau age is obtained when the apparent ages of at least three consecutive steps, comprising a minimum of $70 \%$ of the ${ }^{39} \mathrm{Ar}$ released, agree within $2 \sigma$ error bars with the integrated age of the plateau segment. Nevertheless, pseudo-plateau ages can be calculated with less than $70 \%$ of the ${ }^{39} \mathrm{Ar}$ released, especially when they can be related to multiple mineral components within the dated crystal. All errors are quoted at the $1 \sigma$ level and do not include the errors on the ${ }^{40} \mathrm{Ar}^{*} / 39 \mathrm{Ar}_{\mathrm{K}}$ ratio and age of the monitor. The error on the ${ }^{40} \mathrm{Ar}^{*} /{ }^{39} \mathrm{Ar}_{\mathrm{K}}$ ratio of the monitor is included in the plateau age calculation.

\section{Results}

The results obtained for Th-U-Pb electron probe dating are reported in Table 2 and summarized in Figs. 3 and 4. The ${ }^{40} \mathrm{Ar} /{ }^{39} \mathrm{Ar}$ results are displayed in Table 3 and shown in Figs. 5-7. Data are described according to their geological context and geographical location (Fig. 2).

\subsection{The Neoarchaean domain}

\subsubsection{The eastern granulite Neoarchaean crust}

Monazite ages from 13 samples from the granulite crust exposed from the west of the Mertz glacier to Cape Gray are detailed below (SEM pictures of representative samples presented in Fig. 3, analytical data presented in Table 2).

The 123 in situ analyses of monazites are presented as separated Gaussian curves with time in the abscissa (in Ma) and are compiled on a cumulative Gaussian curve corresponding to age frequencies (Fig. 4A). This curve displays two clear age peaks at $2502 \pm 12 \mathrm{Ma}$ and $1788 \pm 14 \mathrm{Ma}$ with MSWD greater than 5 . The age of the two populations are not completely representative of the geological event as they include some inheritance and mixing ages due to $\mathrm{Pb}$ loss (see below for discussion). Nevertheless, these data clearly indicate two stages of monazite growth. In a PbO versus $\mathrm{ThO}_{2}{ }^{*}$ diagram (Suzuki et al., 1991) (Fig. 4B), most of the data lie along two linear trends corresponding to a $2.45 \mathrm{Ga}$ (filled circle analyses) and a $1.7 \mathrm{Ga}$ (filled squared analyses) event ages. Anlayses scattered between these two pseudo-isochrons correspond to monazites from mylonitic samples with localized biotite-chlorite shear bands. With the exception of the two samples GD04-147 and RPM98-124B, all the monazites lying on the $1.7 \mathrm{Ga}$ pseudo-isochron have $\mathrm{ThO}_{2}{ }^{*}$ content lower than $7 \%\left(\mathrm{ThO}_{2}\right.$ lower than $3 \%$, see Table 2).

Detailed analytical results for each sample are given in Appendix B. Here, we develop results from three samples from C Island (in the Watt Bay) selected for their evident field relationships. They clearly illustrate the general evolution of the Neoarchaean gran-
(A)
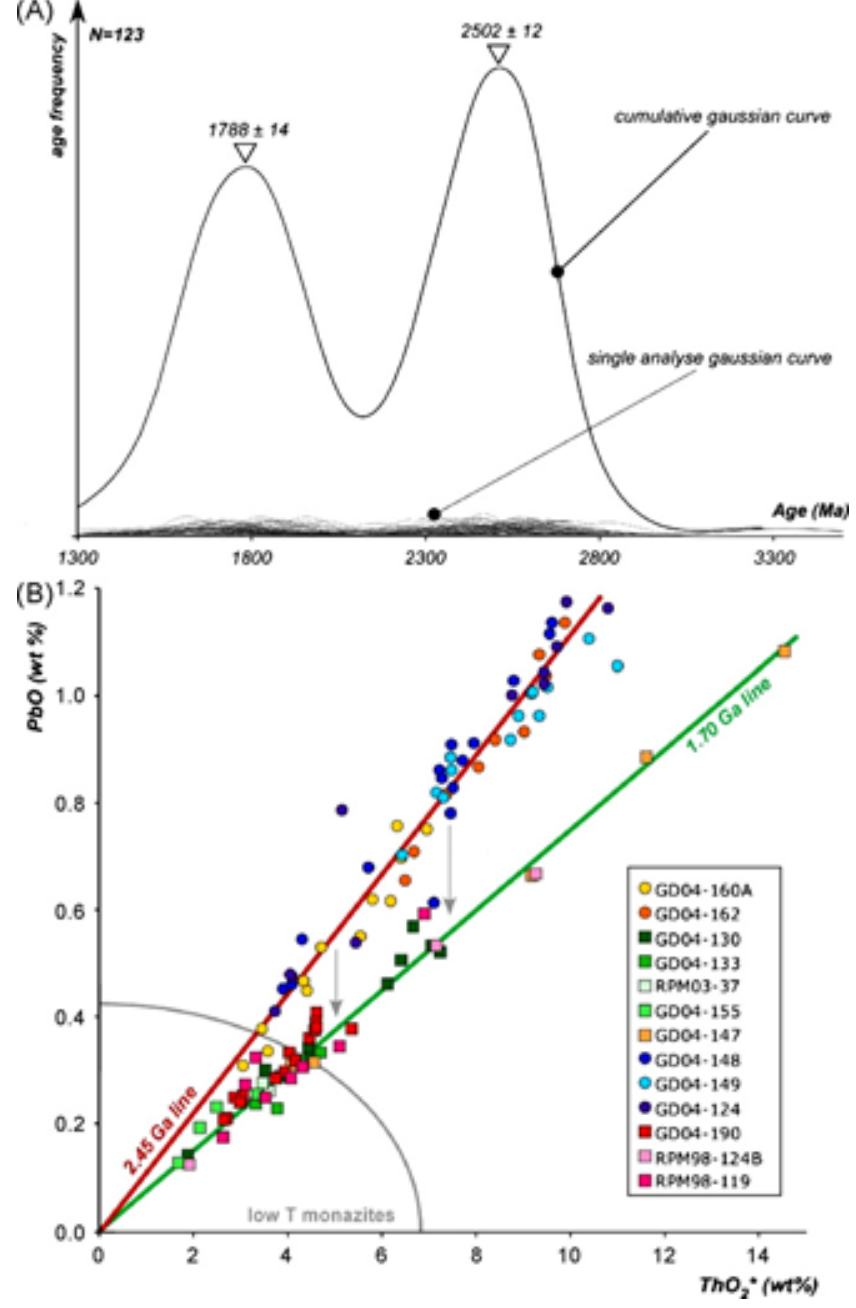

Fig. 4. Monazites data for the Deep Neoarchaean crust. (A) Frequency versus age diagram: age frequencies are represented by a Gaussian cumulative distribution curve and indicate two main monazites growth events. (B) $\mathrm{PbO}$ versus $\mathrm{ThO}_{2}{ }^{*}$ diagram (after Suzuki et al., 1991): most analyses plot on two distinct trends relative to monazites growth age at $2.45 \mathrm{Ga}$ and $1.70 \mathrm{Ga}$. Intermediate analyses are interpreted to reflect partial resetting of $2.45 \mathrm{Ga}$ monazites or age mixing probably linked to later fluid circulation along narrow shear zones at about $1.7 \mathrm{Ga}$. (For interpretation of the references to colour in this figure legend, the reader is referred to the web version of the article.)

ulite crust. Intra-foliation elongated monazites from a fluid-rich mylonitic shear zone (GD04-147: with $\mathrm{qt}+\mathrm{pl}+\mathrm{bt}+\mathrm{chl}$ assemblage) (Fig. 3C and E-G) are dated at $1696 \pm 44$ Ma (MSWD 0.76, $n=6$ ). This shear zone cross-cuts an isotropic hectometre tonalitic body (GD04-149, Fig. 3B and L) with rounded monazites included in plagioclase dated at $2433 \pm 34 \mathrm{Ma}$ (MSWD 1.18, $n=11$ ) that includes foliated mafic xenoliths (GD04-148, Fig. 3A and I) with rounded monazites dated at $2629 \pm 22 \mathrm{Ma}$ (MSWD 2.50, $n=14$ ). Both the tonalitic orthogneiss and its mafic xenoliths record granulite facies conditions (Duclaux, 2007). In contrast to monazites

Fig. 3. Monazites locations for representative samples of the TAC. A-D: thin section photography of samples GD04-149, GD04-149, GD04-147 and GD04-130, indicating (circles) the position of monazites analysed for this study. A and B represent preserved samples from any 1.7 Ga tectonic reworking. C and D correspond to hydrated shear zones where deformation localized during the $1.7 \mathrm{Ga}$ event. Scale is given by the vertical bar of $1 \mathrm{~cm}$ in every picture. (E-L) BSE pictures of monazites from mylonitic samples GD04-147 (E-G), GD04-130 (H) and GD04-190 (J-K), and preserved samples GD04-148 (I) and GD04-149 (L). GD04-147 mylonite contains fine grained shear zones with plagioclase augen crystals (E) and homogeneous monazite crystal (bright phase in the upper centre of the picture, detailed in F) elongate parallel to the shear zone foliation. Monazites also appear associate with hydrated phase as coronae around oxides (G) demonstrating fluid assisted recrystallization process. Monazites from sample GD04-130 (H) and GD04-190 (J-K) are also associated with hydrated phases (mainly biotite). Monazites from preserved granulite samples GD04-148 (I) and GD04-149 (L) are rounded and in equilibrium with plagioclase. 
Table 3

${ }^{40} \mathrm{Ar} /{ }^{39} \mathrm{Ar}$ dating results of DDU samples.

\begin{tabular}{|c|c|c|c|c|c|c|c|}
\hline Step & Laser power (mW) & Atmos pheric conta (\%) & ${ }^{39} \mathrm{Ar}(\%)$ & ${ }^{37} \mathrm{ArCa} /{ }^{39} \mathrm{Ar}_{\mathrm{K}}$ & ${ }^{40} \mathrm{Ar}^{*} / 39 \mathrm{Ar}_{\mathrm{K}}$ & Age $(\mathrm{Ma} \pm 1 \sigma)$ & \\
\hline GD04-174 & Biotite & & & & & & \\
\hline 1 & 250 & 11.911 & 0.12 & 0.004 & 34.934 & 1485.839 & \pm 38.91 \\
\hline 2 & 300 & 0 & 0.11 & 75.473 & 43.892 & 1728.374 & \pm 40.78 \\
\hline 3 & 350 & 4.429 & 0.32 & 0.001 & 36.181 & 1521.618 & \pm 17.80 \\
\hline 4 & 390 & 3.758 & 0.67 & 0.001 & 36.341 & 1526.155 & \pm 8.24 \\
\hline 5 & 440 & 4.373 & 0.95 & - & 36.275 & 1524.283 & \pm 5.79 \\
\hline 6 & 500 & 2.116 & 2.86 & - & 36.681 & 1535.780 & \pm 3.36 \\
\hline 7 & 550 & 1.619 & 4.8 & - & 36.766 & 1538.169 & \pm 2.48 \\
\hline 8 & 590 & 1.737 & 4.37 & - & 36.81 & 1539.388 & \pm 2.59 \\
\hline 9 & 640 & 2.018 & 5.2 & - & 36.672 & 1535.520 & \pm 2.36 \\
\hline 10 & 700 & 0.858 & 9.45 & - & 36.686 & 1535.900 & \pm 1.90 \\
\hline 11 & 750 & 0.767 & 15.48 & - & 36.719 & 1536.827 & \pm 1.76 \\
\hline 12 & 780 & 1.083 & 10.09 & - & 36.663 & 1535.271 & \pm 1.85 \\
\hline 13 & 830 & 0.918 & 10.76 & - & 36.794 & 1538.963 & \pm 1.86 \\
\hline 14 & 900 & 0.904 & 11.01 & - & 36.682 & 1535.799 & \pm 1.75 \\
\hline 15 & 1000 & 0.891 & 10.78 & - & 36.715 & 1536.730 & \pm 1.73 \\
\hline 16 & 1150 & 1.481 & 6.52 & - & 36.781 & 1538.574 & \pm 2.06 \\
\hline 17 & 1400 & 1.507 & 4.21 & - & 36.691 & 1536.046 & \pm 1.93 \\
\hline 18 & 2222 & 2.423 & 2.29 & - & 36.887 & 1541.563 & \pm 8.75 \\
\hline GD04-126 & Biotite & & & & & & \\
\hline 1 & 250 & 5.544 & 0.87 & 38.147 & 28.517 & 1290.669 & \pm 37.70 \\
\hline 2 & 300 & 5.58 & 0.86 & 0.001 & 36.024 & 1518.362 & \pm 36.37 \\
\hline 3 & 350 & 3.705 & 3.04 & - & 38.126 & 1577.288 & \pm 13.59 \\
\hline 4 & 380 & 1.301 & 5.67 & - & 39.382 & 1611.578 & \pm 6.22 \\
\hline 5 & 400 & 1.33 & 5.8 & - & 39.553 & 1616.209 & \pm 6.56 \\
\hline 6 & 420 & 0.287 & 3.74 & 3.823 & 39.537 & 1615.791 & \pm 12.72 \\
\hline 7 & 470 & 2.099 & 7.45 & - & 39.574 & 1616.770 & \pm 5.15 \\
\hline 8 & 530 & 1.636 & 8.68 & - & 39.573 & 1616.760 & \pm 4.15 \\
\hline 9 & 600 & 0.91 & 15.28 & - & 39.345 & 1610.587 & \pm 3.22 \\
\hline 10 & 660 & 1.968 & 9.38 & - & 39.493 & 1614.602 & \pm 4.70 \\
\hline 11 & 750 & 0.966 & 11.91 & - & 39.078 & 1603.350 & \pm 3.13 \\
\hline 12 & 840 & 0.459 & 8.76 & 0.258 & 39.26 & 1608.297 & \pm 6.59 \\
\hline 13 & 1000 & 1.427 & 5.49 & - & 39.336 & 1610.348 & \pm 5.41 \\
\hline 14 & 2222 & 0.977 & 13.08 & - & 39.547 & 1616.042 & \pm 6.21 \\
\hline GD04-120 & Biotite & & & & & & \\
\hline 1 & 250 & 48.894 & 1.28 & 0.004 & 41.502 & 1667.227 & \pm 40.63 \\
\hline 2 & 300 & 0 & 0.6 & 93.06 & 47.156 & 1809.679 & \pm 74.35 \\
\hline 3 & 350 & 9.236 & 3.1 & 0.001 & 35.943 & 1515.266 & \pm 26.29 \\
\hline 4 & 400 & 2.749 & 9.71 & - & 36.058 & 1518.530 & \pm 6.82 \\
\hline 5 & 430 & 20.869 & 4.72 & 0.001 & 36.137 & 1520.774 & \pm 9.88 \\
\hline 6 & 470 & 22.633 & 8.43 & - & 36.084 & 1519.286 & \pm 7.04 \\
\hline 7 & 510 & 51.153 & 3.78 & 0.001 & 36.272 & 1524.607 & \pm 12.60 \\
\hline 8 & 580 & 10.156 & 6.56 & 0.001 & 35.654 & 1506.985 & \pm 9.10 \\
\hline 9 & 700 & 9.131 & 19.71 & - & 35.467 & 1501.630 & \pm 3.91 \\
\hline 10 & 900 & 6.683 & 32.76 & - & 35.676 & 1507.636 & \pm 2.84 \\
\hline 11 & 1100 & 35.852 & 6.9 & - & 35.074 & 1490.293 & \pm 8.48 \\
\hline 12 & 2222 & 86.827 & 2.46 & 0.001 & 36.298 & 1525.344 & \pm 20.65 \\
\hline GD04-183 & Biotite & & & & & & \\
\hline 1 & 250 & 53.953 & 0.17 & 0.001 & 25.014 & 1171.566 & \pm 37.03 \\
\hline 2 & 300 & 29.834 & 0.15 & 0.001 & 35.758 & 1508.236 & \pm 28.74 \\
\hline 3 & 350 & 5.025 & 0.91 & - & 40.398 & 1636.199 & \pm 4.51 \\
\hline 4 & 390 & 3.037 & 1.84 & - & 42.827 & 1699.750 & \pm 3.45 \\
\hline 5 & 420 & 1.416 & 3.17 & - & 42.906 & 1701.781 & \pm 2.29 \\
\hline 6 & 445 & 1.524 & 3.14 & - & 43.04 & 1705.211 & \pm 2.46 \\
\hline 7 & 470 & 1.034 & 4.37 & - & 42.934 & 1702.495 & \pm 1.97 \\
\hline 8 & 490 & 1.054 & 2.72 & - & 42.866 & 1700.760 & \pm 2.50 \\
\hline 9 & 520 & 0.676 & 4.14 & - & 42.941 & 1702.668 & \pm 1.87 \\
\hline 10 & 550 & 0.785 & 5.14 & - & 42.923 & 1702.223 & \pm 2.30 \\
\hline 11 & 580 & 0.203 & 4.39 & - & 42.978 & 1703.642 & \pm 1.98 \\
\hline 12 & 620 & 0.209 & 3.88 & 0.367 & 42.961 & 1703.204 & \pm 2.26 \\
\hline 13 & 700 & 0.619 & 8.52 & - & 42.962 & 1703.215 & \pm 1.72 \\
\hline 14 & 800 & 0.493 & 10.14 & - & 42.839 & 1700.056 & \pm 1.94 \\
\hline 15 & 890 & 0.446 & 11.77 & - & 42.618 & 1694.361 & \pm 4.40 \\
\hline 16 & 940 & 0.586 & 9.69 & - & 42.763 & 1698.101 & \pm 2.31 \\
\hline 17 & 980 & 0.818 & 5.43 & - & 42.675 & 1695.842 & \pm 2.28 \\
\hline 18 & 1030 & 0.765 & 4.35 & - & 42.797 & 1698.980 & \pm 2.23 \\
\hline 19 & 1100 & 0.741 & 3.2 & - & 42.705 & 1696.613 & \pm 2.59 \\
\hline 20 & 1220 & 0.813 & 4.15 & - & 42.765 & 1698.170 & \pm 1.91 \\
\hline 21 & 2222 & 0.503 & 8.73 & - & 42.821 & 1699.587 & \pm 1.66 \\
\hline GD04-216 & Biotite & & & & & & \\
\hline 1 & 250 & 46.258 & 0.48 & 0.001 & 29.039 & 1292.814 & \pm 12.75 \\
\hline
\end{tabular}


Table 3 (Continued)

\begin{tabular}{|c|c|c|c|c|c|c|c|}
\hline Step & Laser power (mW) & Atmos pheric conta (\%) & ${ }^{39} \mathrm{Ar}(\%)$ & ${ }^{37} \mathrm{ArCa} /{ }^{39} \mathrm{Ar}_{\mathrm{K}}$ & ${ }^{40} \mathrm{Ar}^{*} /{ }^{39} \mathrm{Ar}_{\mathrm{K}}$ & Age $(\mathrm{Ma} \pm 1 \sigma)$ & \\
\hline 2 & 300 & 14.711 & 0.72 & 0.001 & 43.765 & 1708.934 & \pm 8.73 \\
\hline 3 & 340 & 4.4 & 3.33 & - & 43.452 & 1701.031 & \pm 2.93 \\
\hline 4 & 360 & 4.594 & 3.25 & - & 43.358 & 1698.631 & \pm 2.79 \\
\hline 5 & 375 & 1.813 & 3.33 & - & 43.358 & 1698.644 & \pm 4.12 \\
\hline 6 & 395 & 3.087 & 4.71 & - & 43.659 & 1706.270 & \pm 2.58 \\
\hline 7 & 415 & 2.043 & 2.27 & - & 43.274 & 1696.495 & \pm 3.99 \\
\hline 8 & 455 & 1.188 & 1.97 & - & 43.49 & 1701.977 & \pm 3.85 \\
\hline 9 & 540 & 0.858 & 5.13 & - & 43.763 & 1708.893 & \pm 2.30 \\
\hline 10 & 600 & 0.792 & 8.14 & - & 43.934 & 1713.205 & \pm 1.95 \\
\hline 11 & 650 & 0.618 & 12.22 & - & 43.709 & 1707.516 & \pm 2.09 \\
\hline 12 & 685 & 1.315 & 7.12 & - & 43.401 & 1699.743 & \pm 2.23 \\
\hline 13 & 745 & 2.057 & 7.1 & - & 43.474 & 1701.582 & \pm 1.91 \\
\hline 14 & 850 & 1.706 & 10.98 & - & 43.425 & 1700.348 & \pm 1.87 \\
\hline 15 & 960 & 1.288 & 15.39 & - & 43.33 & 1697.923 & \pm 3.00 \\
\hline 16 & 1060 & 2.141 & 10.76 & - & 43.444 & 1700.815 & \pm 2.24 \\
\hline 17 & 1200 & 5.966 & 2.17 & - & 43.263 & 1696.218 & \pm 5.61 \\
\hline 18 & 2222 & 16.316 & 0.91 & - & 43.405 & 1699.825 & \pm 7.90 \\
\hline PMA13 & Biotite & & & & & & \\
\hline 1 & 250 & 43.941 & 0.76 & 0.01 & 39.811 & 1622.977 & \pm 68.59 \\
\hline 2 & 300 & 0 & 1.32 & 31.364 & 47.975 & 1830.107 & \pm 33.26 \\
\hline 3 & 350 & 6.402 & 5.04 & 0.001 & 42.387 & 1690.937 & \pm 11.14 \\
\hline 4 & 400 & 3.632 & 12.43 & 0.001 & 42.33 & 1689.450 & \pm 6.24 \\
\hline 5 & 440 & 4.198 & 8.27 & 0.001 & 42.091 & 1683.239 & \pm 8.27 \\
\hline 6 & 500 & 5.723 & 5.91 & 0.001 & 41.877 & 1677.678 & \pm 12.75 \\
\hline 7 & 580 & 7.717 & 5.14 & 0.001 & 41.736 & 1673.998 & \pm 11.96 \\
\hline 8 & 700 & 4.945 & 10.09 & 0.001 & 41.694 & 1672.885 & \pm 7.83 \\
\hline 9 & 900 & 2.046 & 26.91 & - & 41.846 & 1676.868 & \pm 3.30 \\
\hline 10 & 1111 & 4.841 & 24.13 & - & 42.142 & 1684.574 & \pm 3.34 \\
\hline PMA14A & Biotite & & & & & & \\
\hline 1 & 250 & 8.764 & 1.52 & 0.002 & 14.796 & 780.483 & \pm 26.15 \\
\hline 2 & 300 & 22.861 & 0.69 & 0.004 & 35.102 & 1490.161 & \pm 42.10 \\
\hline 3 & 350 & 3.352 & 3.39 & 0.001 & 42.503 & 1692.255 & \pm 8.72 \\
\hline 4 & 400 & 3.55 & 8.07 & - & 42.017 & 1679.648 & \pm 3.85 \\
\hline 5 & 450 & 1.815 & 6.62 & - & 42.356 & 1688.451 & \pm 5.21 \\
\hline 6 & 500 & 4.086 & 5.14 & 0.001 & 42.324 & 1687.624 & \pm 4.44 \\
\hline 7 & 570 & 2.441 & 14.12 & - & 43.126 & 1708.257 & \pm 2.94 \\
\hline 8 & 640 & 1.259 & 19.38 & - & 42.838 & 1700.880 & \pm 2.75 \\
\hline 9 & 700 & 2.786 & 10.26 & - & 42.462 & 1691.196 & \pm 3.00 \\
\hline 10 & 780 & 4.549 & 8.22 & - & 42.345 & 1688.151 & \pm 4.11 \\
\hline 11 & 910 & 1.083 & 13.73 & - & 42.309 & 1687.235 & \pm 3.30 \\
\hline 12 & 1060 & 3.305 & 5.36 & 0.001 & 42.013 & 1679.542 & \pm 6.73 \\
\hline 13 & 2222 & 4.127 & 3.5 & 0.001 & 42.01 & 1679.458 & \pm 14.34 \\
\hline PMA14C & Biotite & & & & & & \\
\hline 1 & 250 & 14.742 & 2.39 & 0.001 & 23.992 & 1135.360 & \pm 16.58 \\
\hline 2 & 300 & 0.287 & 2.7 & 15.688 & 42.874 & 1700.107 & \pm 13.27 \\
\hline 3 & 350 & 3.327 & 7.89 & - & 41.776 & 1671.687 & \pm 6.73 \\
\hline 4 & 400 & 2.049 & 10.58 & - & 41.834 & 1673.211 & \pm 6.66 \\
\hline 5 & 450 & 1.067 & 4.72 & 3.706 & 41.893 & 1674.745 & \pm 7.79 \\
\hline 6 & 500 & 3.278 & 5.68 & - & 42.083 & 1679.700 & \pm 6.73 \\
\hline 7 & 570 & 2.572 & 13.73 & - & 42.496 & 1690.392 & \pm 4.86 \\
\hline 8 & 620 & 1.814 & 14.24 & - & 42.103 & 1680.204 & \pm 3.96 \\
\hline 9 & 670 & 2.548 & 9.06 & - & 41.898 & 1674.874 & \pm 4.88 \\
\hline 10 & 740 & 3.054 & 5.24 & - & 41.558 & 1666.011 & \pm 6.73 \\
\hline 11 & 870 & 0.165 & 9.89 & 2.528 & 41.987 & 1677.206 & \pm 5.28 \\
\hline 12 & 1000 & 0.196 & 9.77 & 3.531 & 42.135 & 1681.034 & \pm 5.06 \\
\hline 13 & 1220 & 3.901 & 2.98 & - & 40.402 & 1635.494 & \pm 12.89 \\
\hline 14 & 2222 & 7.02 & 1.13 & 0.001 & 39.517 & 1611.792 & \pm 29.53 \\
\hline AP99-24 & Muscovite & & & & & & \\
\hline 1 & 250 & 3.42 & 2.97 & - & 40.825 & 1644.411 & \pm 5.05 \\
\hline 2 & 280 & 2.543 & 3.34 & - & 42.537 & 1689.097 & \pm 3.30 \\
\hline 3 & 295 & 0.885 & 8.92 & - & 40.584 & 1638.038 & \pm 2.45 \\
\hline 4 & 305 & 0.761 & 3.89 & - & 39.563 & 1610.749 & \pm 3.49 \\
\hline 5 & 315 & 0.708 & 23.41 & - & 39.305 & 1603.787 & \pm 1.65 \\
\hline 6 & 320 & 2.514 & 4.16 & - & 38.499 & 1581.870 & \pm 3.46 \\
\hline 7 & 335 & 3.937 & 2.85 & - & 38.137 & 1571.928 & \pm 3.40 \\
\hline 8 & 400 & 0.685 & 43.05 & - & 38.702 & 1587.411 & \pm 1.49 \\
\hline 9 & 450 & 0.548 & 3.88 & - & 39.726 & 1615.135 & \pm 3.17 \\
\hline 10 & 550 & 2.849 & 2.51 & - & 40.353 & 1631.885 & \pm 2.91 \\
\hline 11 & 750 & 4.009 & 0.74 & 0.001 & 39.169 & 1600.115 & \pm 15.97 \\
\hline 12 & 2222 & 12.353 & 0.28 & 0.003 & 37.568 & 1556.209 & \pm 37.61 \\
\hline JJP98-18 & Amphibole & & & & & & \\
\hline 1 & 388.0 & 66.186 & 0.04 & 13.191 & 26.562 & 1212.308 & \pm 172.305 \\
\hline
\end{tabular}


Table 3 (Continued)

\begin{tabular}{|c|c|c|c|c|c|c|c|}
\hline Step & Laser power (mW) & Atmos pheric conta (\%) & ${ }^{39} \operatorname{Ar}(\%)$ & ${ }^{37} \mathrm{ArCa} /{ }^{39} \mathrm{Ar}_{\mathrm{K}}$ & ${ }^{40} \mathrm{Ar}^{*} /{ }^{39} \mathrm{Ar}_{\mathrm{K}}$ & Age $(\mathrm{Ma} \pm 1 \sigma)$ & \\
\hline 2 & 442.0 & 21.377 & 0.25 & 2.910 & 38.532 & 1571.795 & \pm 16.376 \\
\hline 3 & 459.0 & - & 0.30 & 1.151 & 44.088 & 1717.076 & \pm 18.218 \\
\hline 4 & 486.0 & - & 0.28 & 1.568 & 43.221 & 1695.172 & \pm 15.360 \\
\hline 5 & 495.0 & - & 0.17 & 2.130 & 44.337 & 1723.316 & \pm 25.739 \\
\hline 6 & 521.0 & 0.448 & 0.54 & 4.847 & 45.357 & 1748.677 & \pm 11.157 \\
\hline 7 & 532.0 & 0.683 & 0.66 & 5.896 & 44.281 & 1721.915 & \pm 12.439 \\
\hline 8 & 551.0 & 0.029 & 1.63 & 6.759 & 43.781 & 1709.338 & \pm 4.179 \\
\hline 9 & 565.0 & - & 4.85 & 7.381 & 44.034 & 1715.716 & \pm 2.697 \\
\hline 10 & 580.0 & - & 10.92 & 7.596 & 43.790 & 1709.563 & \pm 2.771 \\
\hline 11 & 589.0 & - & 37.15 & 7.651 & 44.298 & 1722.348 & \pm 16.771 \\
\hline 12 & 585.0 & - & 11.19 & 7.437 & 43.717 & 1707.729 & \pm 2.164 \\
\hline 13 & 590.0 & - & 4.28 & 7.376 & 43.867 & 1711.503 & \pm 3.008 \\
\hline 14 & 596.0 & - & 2.86 & 7.290 & 43.696 & 1707.204 & \pm 2.883 \\
\hline 15 & 605.0 & - & 12.49 & 7.450 & 43.776 & 1709.230 & \pm 3.445 \\
\hline 16 & 606.0 & - & 0.89 & 7.331 & 43.631 & 1705.564 & \pm 7.660 \\
\hline 17 & 609.0 & - & 0.75 & 6.329 & 43.612 & 1705.086 & \pm 9.280 \\
\hline 18 & 616.0 & - & 2.45 & 7.104 & 43.912 & 1712.648 & \pm 3.947 \\
\hline 19 & 625.0 & - & 0.98 & 6.253 & 43.484 & 1701.846 & \pm 7.262 \\
\hline 20 & 640.0 & 0.874 & 0.43 & 5.812 & 42.762 & 1683.461 & \pm 17.184 \\
\hline 21 & 659.0 & - & 0.87 & 6.796 & 44.312 & 1722.702 & \pm 5.631 \\
\hline 22 & 710.0 & - & 1.70 & 6.719 & 44.432 & 1725.704 & \pm 5.597 \\
\hline 23 & 782.0 & - & 0.43 & 6.850 & 45.545 & 1753.303 & \pm 12.498 \\
\hline 24 & 881.0 & - & 1.89 & 6.593 & 46.709 & 1781.747 & \pm 4.133 \\
\hline 25 & 980.0 & - & 1.99 & 8.028 & 44.362 & 1723.950 & \pm 5.162 \\
\hline JJP98-18 & Biotite & & & & & & \\
\hline 1 & 353.0 & 15.817 & 0.12 & - & 52.233 & 1910.892 & \pm 175.032 \\
\hline 2 & 372.0 & 8.407 & 0.33 & - & 48.094 & 1815.007 & \pm 54.250 \\
\hline 3 & 398.0 & 3.220 & 0.69 & 0.024 & 43.771 & 1709.100 & \pm 19.040 \\
\hline 4 & 422.0 & 0.707 & 1.31 & 0.016 & 43.590 & 1704.524 & \pm 10.726 \\
\hline 5 & 444.0 & 0.116 & 3.15 & 0.002 & 42.869 & 1686.178 & \pm 6.277 \\
\hline 6 & 466.0 & 0.561 & 4.42 & - & 42.448 & 1675.397 & \pm 4.527 \\
\hline 7 & 494.0 & - & 3.65 & - & 42.637 & 1680.254 & \pm 5.756 \\
\hline 8 & 526.0 & - & 2.97 & - & 42.765 & 1683.534 & \pm 6.224 \\
\hline 9 & 556.0 & - & 9.21 & 0.002 & 42.407 & 1674.352 & \pm 2.724 \\
\hline 10 & 580.0 & 0.206 & 7.48 & - & 42.151 & 1667.749 & \pm 3.492 \\
\hline 11 & 610.0 & - & 14.86 & - & 42.047 & 1665.054 & \pm 2.192 \\
\hline 12 & 628.0 & 0.421 & 8.09 & 0.002 & 42.063 & 1665.477 & \pm 3.012 \\
\hline 13 & 675.0 & - & 11.07 & - & 42.215 & 1669.390 & \pm 3.341 \\
\hline 14 & 717.0 & - & 12.55 & - & 42.354 & 1672.975 & \pm 4.004 \\
\hline 15 & 755.0 & - & 15.21 & 0.003 & 42.092 & 1666.206 & \pm 2.325 \\
\hline 16 & 786.0 & 0.168 & 3.22 & 0.004 & 42.346 & 1672.760 & \pm 6.348 \\
\hline 17 & 827.0 & 1.192 & 1.04 & - & 42.378 & 1673.602 & \pm 15.805 \\
\hline 18 & 900.0 & 1.018 & 0.64 & 0.029 & 43.154 & 1693.452 & \pm 24.613 \\
\hline JJP98-17 & Amphibole & & & & & & \\
\hline 1 & 365.0 & 14.229 & 0.02 & 9.325 & 72.884 & 2325.387 & \pm 280.793 \\
\hline 2 & 379.0 & 15.475 & 0.01 & 7.002 & 48.324 & 1820.483 & \pm 347.986 \\
\hline 3 & 394.0 & - & 0.02 & 7.272 & 62.727 & 2133.375 & \pm 240.383 \\
\hline 4 & 426.0 & - & 0.01 & 25.483 & 219.190 & 3945.106 & \pm 406.027 \\
\hline 5 & 441.0 & - & 0.25 & 7.001 & 53.543 & 1940.216 & \pm 26.561 \\
\hline 6 & 455.0 & 1.811 & 0.36 & 6.894 & 45.538 & 1753.150 & \pm 19.969 \\
\hline 7 & 469.0 & - & 5.92 & 6.790 & 43.688 & 1706.990 & \pm 2.733 \\
\hline 8 & 474.0 & - & 3.48 & 6.861 & 43.396 & 1699.612 & \pm 3.335 \\
\hline 9 & 479.0 & - & 3.22 & 6.833 & 43.426 & 1700.361 & \pm 3.316 \\
\hline 10 & 484.0 & - & 8.36 & 6.929 & 43.467 & 1701.395 & \pm 2.800 \\
\hline 11 & 490.0 & - & 0.45 & 6.985 & 43.975 & 1714.223 & \pm 13.048 \\
\hline 12 & 502.0 & - & 1.04 & 6.939 & 43.941 & 1713.364 & \pm 8.540 \\
\hline 13 & 509.0 & - & 1.59 & 6.884 & 43.698 & 1707.261 & \pm 6.331 \\
\hline 14 & 520.0 & - & 3.05 & 6.796 & 43.612 & 1705.083 & \pm 2.724 \\
\hline 15 & 530.0 & - & 9.36 & 6.789 & 43.414 & 1700.053 & \pm 2.774 \\
\hline 16 & 535.0 & - & 3.48 & 6.786 & 43.358 & 1698.642 & \pm 3.743 \\
\hline 17 & 541.0 & - & 3.58 & 6.801 & 43.328 & 1697.882 & \pm 3.321 \\
\hline 18 & 547.0 & - & 3.62 & 6.855 & 43.648 & 1705.994 & \pm 2.992 \\
\hline 19 & 554.0 & - & 8.74 & 6.755 & 43.407 & 1699.892 & \pm 3.806 \\
\hline 20 & 560.0 & - & 2.39 & 6.764 & 43.458 & 1701.169 & \pm 4.511 \\
\hline 21 & 565.0 & - & 2.95 & 6.748 & 43.373 & 1699.023 & \pm 3.979 \\
\hline 22 & 570.0 & - & 6.05 & 6.718 & 43.690 & 1707.058 & \pm 7.738 \\
\hline 23 & 571.0 & - & 6.36 & 6.789 & 43.484 & 1701.836 & \pm 2.483 \\
\hline 24 & 576.0 & - & 5.78 & 6.754 & 43.415 & 1700.095 & \pm 2.424 \\
\hline 25 & 581.0 & - & 2.79 & 6.712 & 43.525 & 1702.862 & \pm 4.433 \\
\hline 26 & 588.0 & - & 7.18 & 6.748 & 43.435 & 1700.597 & \pm 2.193 \\
\hline 27 & 596.0 & - & 2.24 & 6.852 & 43.497 & 1702.153 & \pm 4.783 \\
\hline 28 & 612.0 & 0.530 & 0.57 & 6.920 & 43.254 & 1696.007 & \pm 13.817 \\
\hline 29 & 641.0 & - & 3.14 & 6.676 & 43.719 & 1707.776 & \pm 3.347 \\
\hline 30 & 672.0 & - & 0.25 & 6.859 & 46.852 & 1785.202 & \pm 39.735 \\
\hline
\end{tabular}


Table 3 (Continued)

\begin{tabular}{|c|c|c|c|c|c|c|c|}
\hline Step & Laser power (mW) & Atmos pheric conta (\%) & ${ }^{39} \operatorname{Ar}(\%)$ & ${ }^{37} \mathrm{ArCa} /{ }^{39} \mathrm{Ar}_{\mathrm{K}}$ & ${ }^{40} \mathrm{Ar}^{*} /{ }^{39} \mathrm{Ar}_{\mathrm{K}}$ & Age $(\mathrm{Ma} \pm 1 \sigma)$ & \\
\hline 31 & 762.0 & - & 2.97 & 6.777 & 44.014 & 1715.217 & \pm 3.217 \\
\hline 32 & 800.0 & 0.597 & 0.80 & 6.953 & 43.745 & 1708.435 & \pm 9.435 \\
\hline JJP98-17 & Biotite & & & & & & \\
\hline 1 & 339.0 & 1.605 & 1.02 & - & 49.172 & 1840.479 & \pm 23.826 \\
\hline 2 & 356.0 & - & 4.10 & 0.015 & 44.342 & 1723.433 & \pm 6.317 \\
\hline 3 & 374.0 & - & 6.54 & 0.008 & 43.810 & 1710.067 & \pm 4.402 \\
\hline 4 & 392.0 & - & 7.97 & 0.012 & 43.922 & 1712.891 & \pm 3.241 \\
\hline 5 & 412.0 & - & 4.48 & 0.007 & 43.736 & 1708.220 & \pm 6.878 \\
\hline 6 & 432.0 & 0.354 & 5.07 & 0.026 & 43.298 & 1697.126 & \pm 5.103 \\
\hline 7 & 455.0 & 0.177 & 14.39 & 0.009 & 42.424 & 1674.785 & \pm 4.312 \\
\hline 8 & 477.0 & 0.074 & 12.08 & 0.013 & 42.525 & 1677.366 & \pm 3.298 \\
\hline 9 & 497.0 & 0.234 & 7.52 & 0.012 & 42.370 & 1673.382 & \pm 4.085 \\
\hline 10 & 519.0 & 0.115 & 6.69 & 0.022 & 42.515 & 1677.117 & \pm 4.778 \\
\hline 11 & 538.0 & - & 7.77 & 0.013 & 42.631 & 1680.095 & \pm 4.702 \\
\hline 12 & 558.0 & - & 4.19 & 0.028 & 43.279 & 1696.642 & \pm 7.623 \\
\hline 13 & 577.0 & 0.141 & 9.90 & 0.015 & 42.526 & 1677.399 & \pm 4.187 \\
\hline 14 & 596.0 & 0.381 & 2.58 & 0.049 & 42.963 & 1688.587 & \pm 10.254 \\
\hline 15 & 620.0 & 1.272 & 3.43 & 0.026 & 42.221 & 1669.537 & \pm 8.406 \\
\hline 16 & 645.0 & - & 1.80 & - & 42.647 & 1680.509 & \pm 11.860 \\
\hline 17 & 676.0 & 5.387 & 0.20 & 0.164 & 42.790 & 1684.173 & \pm 108.002 \\
\hline 18 & 1550.0 & - & 0.28 & - & 43.596 & 1704.672 & \pm 63.996 \\
\hline JJP98-6 & Amphibole & & & & & & \\
\hline 1 & 434.0 & 4.852 & 0.20 & 5.598 & 114.756 & 2953.147 & \pm 21.071 \\
\hline 2 & 464.0 & - & 45.20 & 5.705 & 43.414 & 1700.067 & \pm 13.968 \\
\hline 3 & 469.0 & - & 27.05 & 5.738 & 43.825 & 1710.451 & \pm 29.243 \\
\hline 4 & 473.0 & - & 3.65 & 5.774 & 43.485 & 1701.857 & \pm 3.744 \\
\hline 5 & 455.0 & - & 23.89 & 5.655 & 43.635 & 1705.650 & \pm 27.813 \\
\hline JJP98-6 & Biotite & & & & & & \\
\hline 1 & 322.0 & 2.401 & 3.00 & 0.022 & 43.938 & 1713.299 & \pm 5.321 \\
\hline 2 & 343.0 & 0.009 & 4.98 & 0.008 & 43.087 & 1691.761 & \pm 4.158 \\
\hline 3 & 363.0 & - & 8.60 & 0.002 & 42.991 & 1689.292 & \pm 2.830 \\
\hline 4 & 384.0 & 0.046 & 8.67 & 0.002 & 42.488 & 1676.412 & \pm 2.672 \\
\hline 5 & 403.0 & 0.123 & 6.88 & 0.011 & 42.389 & 1673.868 & \pm 3.575 \\
\hline 6 & 445.0 & 0.030 & 8.14 & 0.009 & 42.004 & 1663.938 & \pm 3.052 \\
\hline 7 & 465.0 & 0.152 & 14.95 & 0.004 & 41.648 & 1654.715 & \pm 3.207 \\
\hline 8 & 486.0 & 0.494 & 1.77 & 0.016 & 41.303 & 1645.726 & \pm 8.771 \\
\hline 9 & 511.0 & 1.146 & 3.97 & 0.038 & 40.894 & 1634.989 & \pm 4.829 \\
\hline 10 & 535.0 & 0.054 & 4.07 & 0.010 & 41.667 & 1655.213 & \pm 3.563 \\
\hline 11 & 555.0 & 0.053 & 8.50 & 0.004 & 41.536 & 1651.796 & \pm 3.255 \\
\hline 12 & 575.0 & 0.048 & 5.06 & 0.003 & 41.906 & 1661.416 & \pm 4.066 \\
\hline 13 & 595.0 & - & 4.43 & 0.007 & 42.137 & 1667.384 & \pm 3.800 \\
\hline 14 & 616.0 & - & 3.05 & 0.015 & 42.296 & 1671.484 & \pm 5.859 \\
\hline 15 & 636.0 & - & 10.27 & 0.010 & 41.839 & 1659.661 & \pm 2.622 \\
\hline 16 & 658.0 & - & 3.65 & - & 41.722 & 1656.644 & \pm 6.497 \\
\hline AP99-36 & Amphibole & & & & & & \\
\hline 1 & 368.0 & 23.380 & 0.11 & 40.283 & 85.614 & 2540.317 & \pm 40.133 \\
\hline 2 & 420.0 & 5.219 & 0.30 & 7.118 & 48.296 & 1819.797 & \pm 18.937 \\
\hline 3 & 458.0 & 0.842 & 0.78 & 3.200 & 42.914 & 1687.324 & \pm 7.544 \\
\hline 4 & 475.0 & - & 0.43 & 3.840 & 41.951 & 1662.582 & \pm 15.431 \\
\hline 5 & 469.0 & - & 0.42 & 5.251 & 43.575 & 1704.127 & \pm 14.557 \\
\hline 6 & 480.0 & - & 0.59 & 6.503 & 43.287 & 1696.828 & \pm 15.646 \\
\hline 7 & 484.0 & 0.258 & 0.88 & 7.089 & 42.980 & 1689.032 & \pm 10.756 \\
\hline 8 & 487.0 & 0.295 & 1.63 & 7.020 & 42.516 & 1677.143 & \pm 4.718 \\
\hline 9 & 498.0 & - & 5.68 & 6.818 & 42.312 & 1671.885 & \pm 2.422 \\
\hline 10 & 502.0 & - & 7.18 & 6.655 & 42.281 & 1671.088 & \pm 2.065 \\
\hline 11 & 508.0 & - & 2.33 & 6.489 & 42.248 & 1670.251 & \pm 3.902 \\
\hline 12 & 514.0 & - & 3.79 & 6.506 & 42.331 & 1672.380 & \pm 3.086 \\
\hline 13 & 519.0 & - & 8.67 & 6.546 & 42.394 & 1674.007 & \pm 2.575 \\
\hline 14 & 522.0 & - & 6.43 & 6.532 & 42.284 & 1671.183 & \pm 2.590 \\
\hline 15 & 523.0 & - & 2.78 & 6.485 & 42.202 & 1669.051 & \pm 3.094 \\
\hline 16 & 526.0 & - & 1.40 & 6.529 & 42.785 & 1684.039 & \pm 7.148 \\
\hline 17 & 532.0 & - & 5.17 & 6.493 & 42.499 & 1676.697 & \pm 3.975 \\
\hline 18 & 538.0 & - & 2.84 & 6.523 & 42.886 & 1686.633 & \pm 9.910 \\
\hline 19 & 520.0 & - & 7.53 & 6.455 & 42.327 & 1672.280 & \pm 3.071 \\
\hline 20 & 538.0 & - & 1.70 & 6.145 & 42.806 & 1684.579 & \pm 4.513 \\
\hline 21 & 549.0 & - & 5.65 & 6.393 & 42.499 & 1676.699 & \pm 2.762 \\
\hline 22 & 560.0 & - & 14.28 & 6.461 & 42.403 & 1674.249 & \pm 1.972 \\
\hline 23 & 563.0 & - & 2.51 & 5.996 & 42.165 & 1668.102 & \pm 4.001 \\
\hline 24 & 568.0 & - & 1.94 & 5.819 & 42.294 & 1671.427 & \pm 4.664 \\
\hline 25 & 570.0 & - & 0.48 & 14.690 & 44.027 & 1715.544 & \pm 16.130 \\
\hline 26 & 583.0 & - & 0.47 & 6.768 & 42.421 & 1674.692 & \pm 13.672 \\
\hline 27 & 613.0 & - & 0.33 & 10.773 & 43.784 & 1709.428 & \pm 18.782 \\
\hline
\end{tabular}


Table 3 (Continued)

\begin{tabular}{|c|c|c|c|c|c|c|c|}
\hline Step & Laser power (mW) & Atmos pheric conta (\%) & ${ }^{39} \operatorname{Ar}(\%)$ & ${ }^{37} \mathrm{ArCa} /{ }^{39} \mathrm{Ar}_{\mathrm{K}}$ & ${ }^{40} \mathrm{Ar}^{*} /{ }^{39} \mathrm{Ar}_{\mathrm{K}}$ & Age $(\mathrm{Ma} \pm 1 \sigma)$ & \\
\hline 28 & 647.0 & - & 1.12 & 6.980 & 42.258 & 1670.510 & \pm 7.272 \\
\hline 29 & 694.0 & - & 2.87 & 6.951 & 42.495 & 1676.612 & \pm 3.019 \\
\hline 30 & 770.0 & - & 1.92 & 4.905 & 41.932 & 1662.082 & \pm 4.468 \\
\hline 31 & 810.0 & - & 7.79 & 5.025 & 42.588 & 1678.996 & \pm 1.875 \\
\hline JJP98-4 & Biotite & & & & & & \\
\hline 1 & 335.0 & - & 0.08 & - & 57.953 & 2035.550 & \pm 225.017 \\
\hline 2 & 353.0 & - & 1.24 & - & 44.797 & 1734.793 & \pm 16.018 \\
\hline 3 & 370.0 & - & 0.31 & 0.070 & 43.603 & 1704.838 & \pm 53.241 \\
\hline 4 & 402.0 & 0.788 & 1.79 & - & 41.010 & 1638.051 & \pm 9.199 \\
\hline 5 & 423.0 & 0.474 & 3.72 & 0.019 & 41.111 & 1640.682 & \pm 5.381 \\
\hline 6 & 444.0 & - & 5.30 & 0.024 & 40.991 & 1637.546 & \pm 3.737 \\
\hline 7 & 464.0 & 0.052 & 4.54 & 0.020 & 40.803 & 1632.603 & \pm 4.899 \\
\hline 8 & 494.0 & - & 7.46 & 0.008 & 40.562 & 1626.235 & \pm 3.021 \\
\hline 9 & 523.0 & 0.043 & 8.36 & 0.007 & 40.476 & 1623.969 & \pm 3.174 \\
\hline 10 & 555.0 & 0.362 & 9.58 & 0.005 & 40.064 & 1613.045 & \pm 3.048 \\
\hline 11 & 585.0 & 0.089 & 24.26 & 0.002 & 40.250 & 1617.990 & \pm 1.996 \\
\hline 12 & 599.0 & 1.770 & 1.51 & 0.011 & 39.587 & 1600.301 & \pm 11.879 \\
\hline 13 & 631.0 & 0.091 & 4.83 & 0.003 & 40.238 & 1617.669 & \pm 4.345 \\
\hline 14 & 660.0 & 0.392 & 5.60 & - & 40.218 & 1617.120 & \pm 4.058 \\
\hline 15 & 696.0 & - & 8.42 & - & 40.385 & 1621.554 & \pm 3.793 \\
\hline 16 & 724.0 & 0.485 & 3.97 & - & 40.353 & 1620.703 & \pm 5.374 \\
\hline 17 & 782.0 & - & 5.64 & 0.008 & 40.156 & 1615.471 & \pm 4.119 \\
\hline 18 & 940.0 & - & 1.51 & - & 40.126 & 1614.679 & \pm 14.777 \\
\hline 19 & 1111.0 & - & 1.88 & 0.009 & 40.651 & 1628.596 & \pm 10.361 \\
\hline OM110-1 & Biotite & & & & & & \\
\hline 1 & 326.0 & 1.809 & 2.11 & 0.016 & 40.456 & 1623.431 & \pm 23.664 \\
\hline 2 & 346.0 & 13.392 & 0.20 & 0.282 & 40.474 & 1623.914 & \pm 199.643 \\
\hline 3 & 376.0 & 0.514 & 16.41 & 0.008 & 39.424 & 1595.916 & \pm 4.290 \\
\hline 4 & 398.0 & 0.076 & 12.81 & 0.007 & 38.854 & 1580.532 & \pm 5.706 \\
\hline 5 & 420.0 & 0.139 & 7.21 & 0.001 & 38.937 & 1582.799 & \pm 7.171 \\
\hline 6 & 450.0 & 0.352 & 5.84 & 0.015 & 38.957 & 1583.332 & \pm 9.710 \\
\hline 7 & 488.0 & - & 5.72 & 0.000 & 38.595 & 1573.504 & \pm 6.363 \\
\hline 8 & 535.0 & - & 16.17 & 0.015 & 38.824 & 1579.720 & \pm 4.098 \\
\hline 9 & 581.0 & - & 15.18 & 0.011 & 38.915 & 1582.193 & \pm 3.130 \\
\hline 10 & 622.0 & - & 10.70 & - & 38.927 & 1582.530 & \pm 5.793 \\
\hline 11 & 663.0 & - & 3.98 & - & 39.160 & 1588.814 & \pm 16.695 \\
\hline 12 & 723.0 & - & 3.67 & - & 39.030 & 1585.300 & \pm 11.355 \\
\hline DDU89 & Muscovite & & & & & & \\
\hline 1 & 327.0 & 1.809 & 32.15 & 0.013 & 40.313 & 1619.646 & \pm 4.216 \\
\hline 2 & 328.0 & 0.935 & 10.26 & 0.051 & 39.234 & 1590.799 & \pm 9.845 \\
\hline 3 & 332.0 & 1.786 & 5.51 & 0.104 & 39.502 & 1598.006 & \pm 18.031 \\
\hline 4 & 342.0 & 0.295 & 45.95 & 0.006 & 39.217 & 1590.344 & \pm 3.859 \\
\hline 5 & 348.0 & 0.601 & 6.13 & 0.063 & 39.221 & 1590.456 & \pm 14.453 \\
\hline
\end{tabular}

from the narrow shear zones within the Neoarchaean crust, monazite ages from mylonitic gneiss at Aurora Peak, adjacent to the MSZ, record a slightly younger age at $1619 \pm 48$ Ma (MSWD 0.97 , $n=10)$.

In the Neoarchaean granulite crust, ${ }^{40} \mathrm{Ar} /{ }^{39} \mathrm{Ar}$ analyses of biotites (Fig. 5) display rather flat age spectra allowing plateau age calculations in the range $1509 \pm 3 \mathrm{Ma}$ (sample GD04-120, Stillwell Island) to $1702 \pm 3 \mathrm{Ma}$ (GD04-183, Cape Gray), with intermediate plateau ages at $1537 \pm 3 \mathrm{Ma}$ (sample GD04-174, Close Island) and $1612 \pm 3$ Ma (sample GD04-126, Cape Pigeon).

\subsubsection{The western amphibolite Neoarchaean crust}

In comparison with biotites from the granulite crust, ${ }^{40} \mathrm{Ar} /{ }^{39} \mathrm{Ar}$ analyses of biotites from the amphibolite crust (Fig. 6) display slightly disturbed age spectra with slight humped shapes, with the exception of sample PMA13. Such hump shapes indicate a slight chloritization of the biotites (Ruffet et al., 1991). These authors suggest that the high temperature pseudo-plateau ages could be the best estimates of the true ages of the analysed biotites. Calculated plateau and pseudo-plateau ages are globally older and less scattered than ${ }^{40} \mathrm{Ar} /{ }^{39} \mathrm{Ar}$ biotite ages from granulitic domain. They range between $1678 \pm 3 \mathrm{Ma}$ (PMA14C, Port Martin) and $1700 \pm 3 \mathrm{Ma}$ in (GD04-216, Cap de la Découverte), with intermediate ages at 1681 \pm 3 Ma (PMA13,
Port Martin) and $1687 \pm 3 \mathrm{Ma}$ also in Port Martin (PMA14A, Fig. 8E).

\subsection{Paleoproterozoic basins}

\subsubsection{The Cape Hunter basin}

${ }^{40} \mathrm{Ar} /{ }^{39} \mathrm{Ar}$ dating of a muscovite (AP99-24, Fig. 7) from the Cape Hunter phyllite (Fig. 8D) yields a saddle shaped age spectrum. Such an age spectrum for a single grain of muscovite has been interpreted to reflect the mixing of two age components, an inherited or initial mineral phase and a recrystallized or neocrystallized phase, which may or may not be linked to deformation (Cheilletz et al., 1999; Castonguay et al., 2001; Alexandrov et al., 2002). The saddle-shaped age spectrum results from the existence of different reservoirs with distinct argon compositions in the partially recrystallized muscovite grains, with "shifted" argon degassing of a primary unrecrystallized domain and a neo- or re-crystallized one. This younger neo- or re-crystallized subdomain indicates either a thermal event, at or younger than $1589 \pm 3 \mathrm{Ma}$, unrelated to the crystallization of the initial muscovite which occurred at or prior to $c a$. $1640 \mathrm{Ma}$, or the last isotopic record of a protracted (re)crystallization history during slow cooling, between $1640 \mathrm{Ma}$ and $1589 \mathrm{Ma}$. 

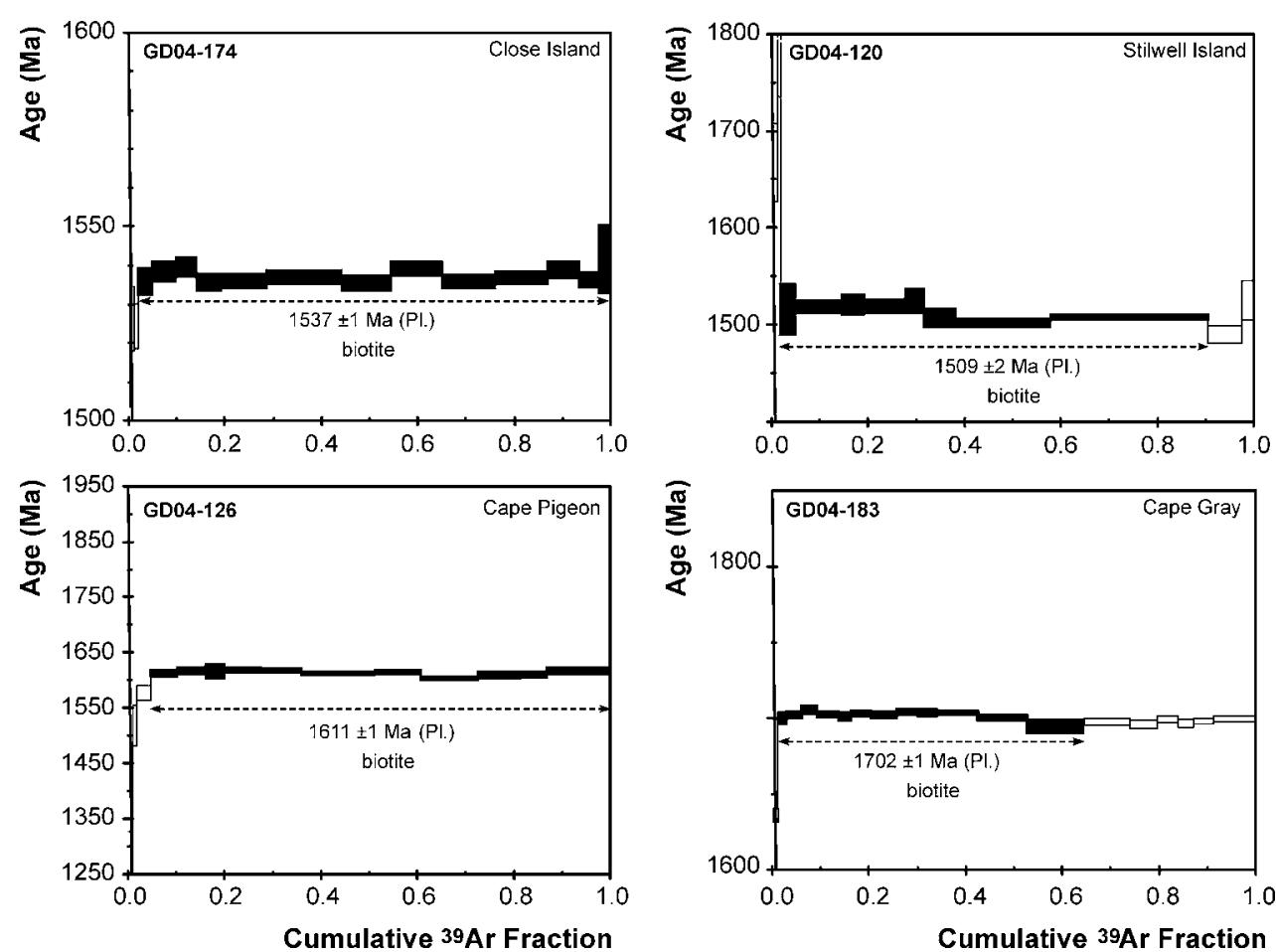

Fig. 5. Argon spectra for the Deep Neoarchaean crust.

4.2.2. The Dumont D'Urville basin

In the eastern region of the Dumont D'Urville basin, Cap Jules samples exhibit ${ }^{40} \mathrm{Ar} /{ }^{39} \mathrm{Ar}$ plateau ages in all analysed amphibole and biotite samples (Fig. 7). Biotite ages range between $1643 \pm 3 \mathrm{Ma}$ (JJP98-6) and 1664 \pm 3 Ma (JJP98-17), with an intermediate age of $1654 \pm 3 \mathrm{Ma}$ (sample JJP98-18). Amphibole ages range between
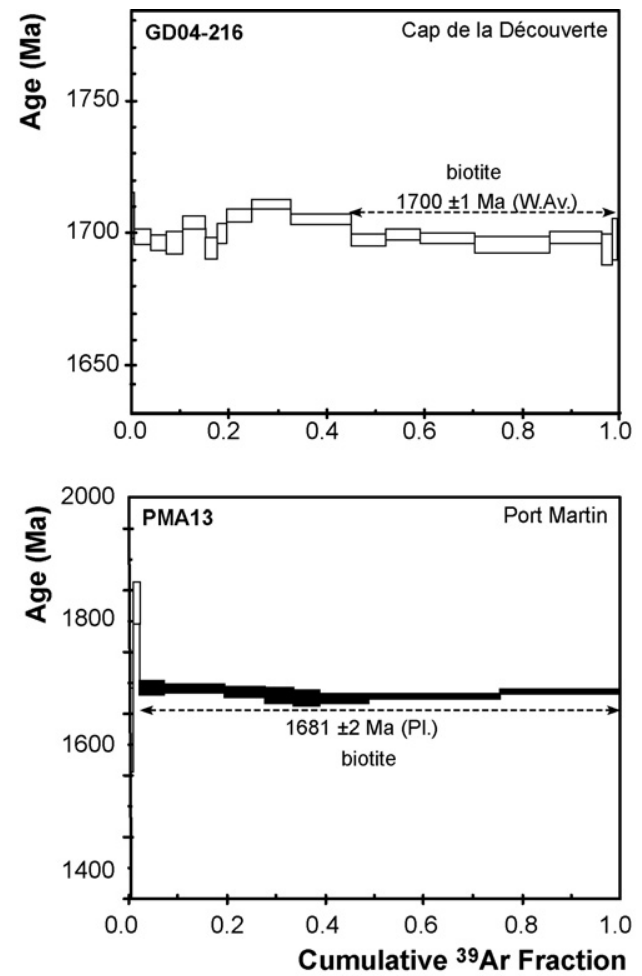

$1678 \pm 3 \mathrm{Ma}(\mathrm{JJP} 98-17)$ and $1691 \pm 7 \mathrm{Ma}$ (JJP98-18), with an intermediate age of $1682 \pm 12 \mathrm{Ma}(\mathrm{JJP} 98-6)$.

Further west, the Cap Bienvenüe biotite sample displays (Fig. 7) a pseudo-plateau age of $1606 \pm 3 \mathrm{Ma}$ (JJP98-4). Amphibole from the same locality records a plateau age of $1651 \pm 3 \mathrm{Ma}$ (AP99-36).
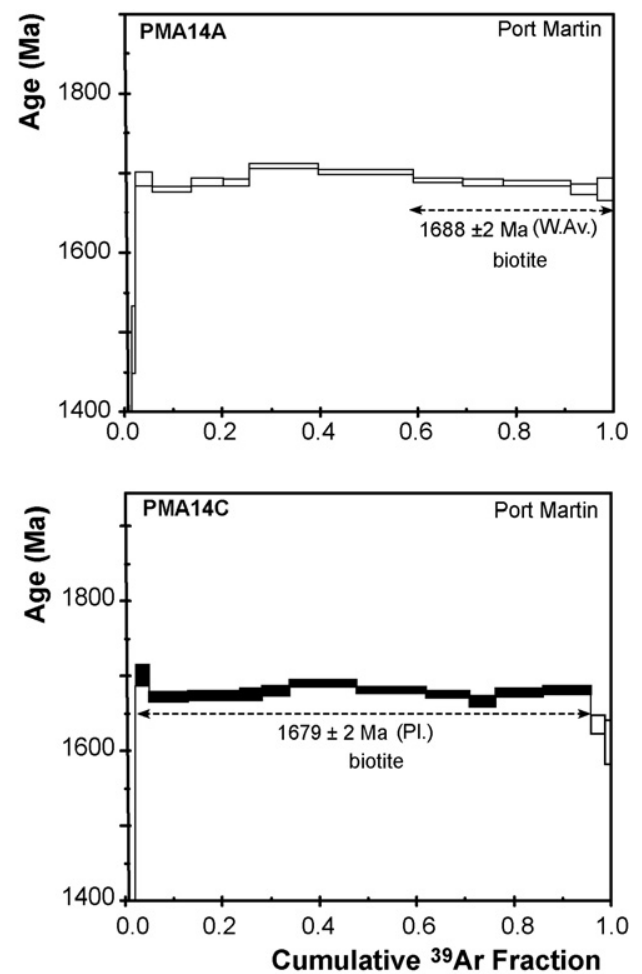

Fig. 6. Argon spectra for the Intermediate to upper Neoarchaean crust. 

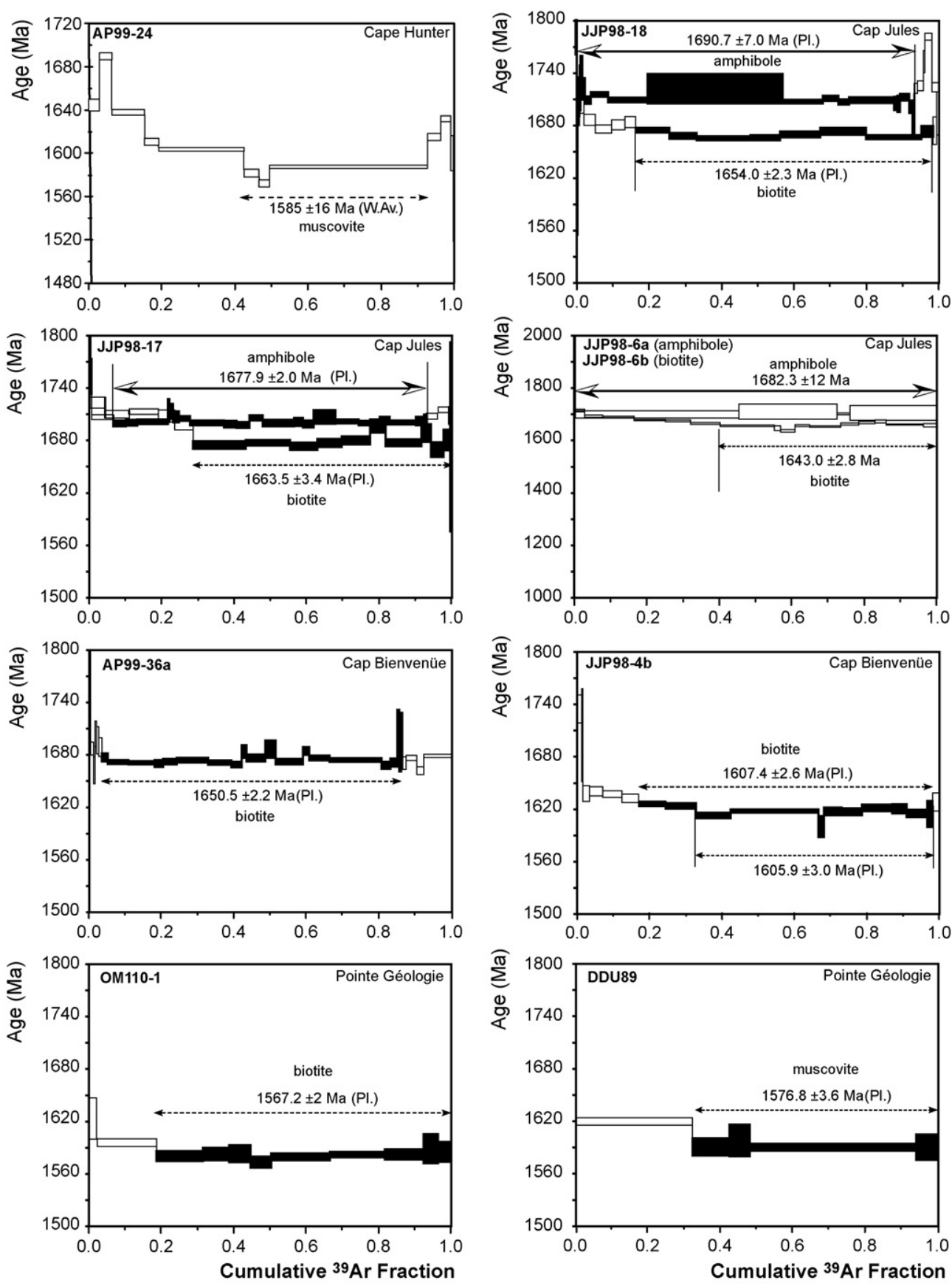

Fig. 7. Argon spectra for the Paleoproterozoic basins.

Finally, Pointe Géologie samples (Fig. 7) yield a plateau age of 1567.2 $\pm 2.2 \mathrm{Ma}$ (biotite OM110-1) and a pseudo-plateau age of $1576.8 \pm 3.6 \mathrm{Ma}$ (muscovite DDU89).

This clearly points out decreasing plateau ages from East to West in the Dumont d'Urville basin, i.e. from Cap Jules towards Pointe Géologie (Fig. 9).

\section{Discussion}

In the following section, we interpret the new Th-U-Pb and ${ }^{40} \mathrm{Ar} /{ }^{39} \mathrm{Ar}$ geochronological data presented above together with previously published ages (Peucat et al., 1999a,b; Oliver and Fanning, 2002; Di Vincenzo et al., 2007). The aim of this discussion is to outline the tectonic history and geodynamic evolution of the TAC's different domains. Scattered ages seem to indicate a three-step tectonic history reworking a 2.8-2.6 Ga juvenile crust.

\subsection{Significance of the $T h-U-P b$ monazite and $U-P b$ zircon data}

\subsubsection{The Neoarchaean crust}

Monazite analyses from the deep Neoarchaean crust illustrate a complex and polyphase tectonic and metamorphic evolution with two major events, occasional inheritance, and partial resetting.

Monazites from preserved granulite and amphibolite facies rocks record a major tectonothermal event between $2477 \mathrm{Ma}$ and 2433 Ma. Peucat et al. (1999b) and Oliver and Fanning (2002) also record U-Pb SHRIMP ages around $2.44 \mathrm{Ga}$ in the grey gneisses of 

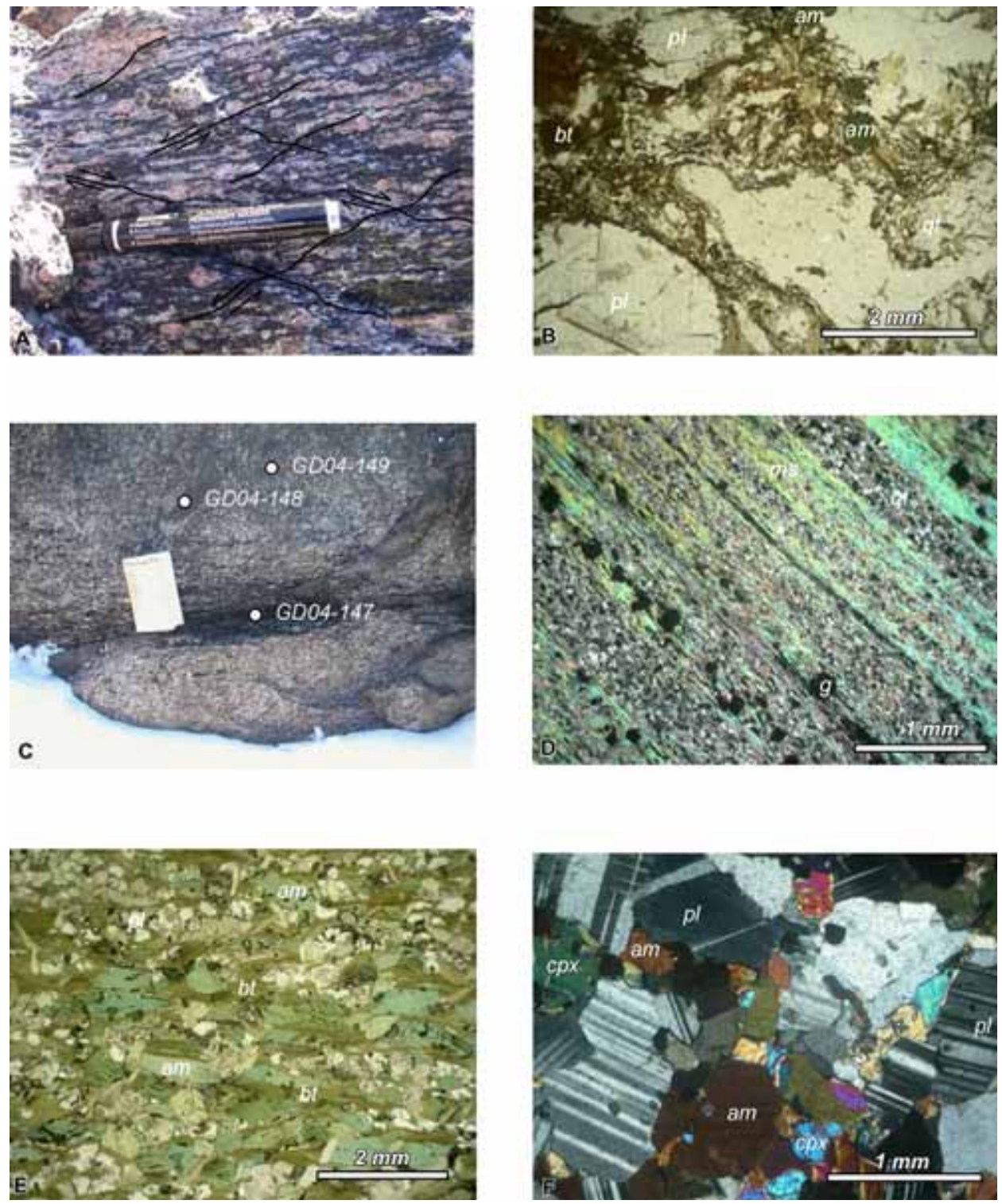

Fig. 8. Photography plate. (A and B) Strained and meta-granodiorites from Correll Nunatak recrystallized under greenschist facies conditions. Image A illustrates the conjugate senses of shear observed on the Mertz Shear zone; Image B shows the replacement of amphibole by biotite along shear zones; (C) C Island samples relationship underlining the small scale $1.7 \mathrm{Ga}$ resetting along narrow shear zones within the Neoarchaean crust (see text for details); (D) Microscope view of the Cape Hunter phyllite. A primary stratification remains recognisable, underlined by qt-rich and ms-rich layers alternation. (E) Port Martin mafic xenolith (PMA14A) illustrating the static retrogression of amphiboles in green biotite; (F) Syntectonic gabbro from the Cap Jules (JJP98-17) illustrating the preservation of magmatic fabric.

the Port Martin and Cape Denison. This age range is interpreted to be the age of the HT granulite facies metamorphism and of subsequent migmatization during granulite to amphibolite facies retrogression associated with decompression around $2.45-2.43 \mathrm{Ga}$ (Duclaux, 2007).

Rounded monazites included in plagioclase from sample GD04148, (a mafic xenolith, Fig. 3A and I) and from sample GD04-124 (an anatectic granite) display age populations of $\mathrm{ca} .2 .63 \mathrm{Ga}$ and ca. $2.59 \mathrm{Ga}$ respectively. Further west, in the intermediate to upper amphibolitic crustal Neoarchaean subdomain, inherited zircons have also been dated by Peucat et al. (1999b) between $2.7 \mathrm{Ga}$ and $2.6 \mathrm{Ga}$. Moreover, these authors have interpreted $\mathrm{Nd}$ model ages from grey gneiss between $2.6 \mathrm{Ga}$ and $2.8 \mathrm{Ga}$ to be associated to a previous period of major continental crust genesis.

The second major event is defined by the 1696-1712 Ma population ages. These ages are found throughout the granulite crust, but localized within decimetre to metre scale shear zones. This is well exemplified on C Island (Figs. 3C, E-G and 8C), where GD04-147 (shear zone: $1696 \mathrm{Ma}$ ) and GD04-149 (isotropic granulitic tonalite: $2433 \mathrm{Ma}$ ) samples are separated by only a few metres. In this case neither the isotropic tonalite sample, nor the xenoliths record any latter resetting. A zircon SHRIMP U-Pb age at $1.70 \mathrm{Ga}$ has also been obtained by Oliver and Fanning (2002) in a sheared Neoarchaean orthopyroxene bearing mafic gneiss from Madigan Nunatak, south of Cape Denison.

The population age between $2.2 \mathrm{Ga}$ and $1.82 \mathrm{Ga}$ is not easily interpreted in terms of tectonic reactivation. Monazites dated in this age range are poorer in $\mathrm{ThO}_{2}$ (here $<3 \mathrm{wt} \%$, see Table 2), which seems to be symptomatic of low temperature reequilibration (Wing et al., 2003; Finger and Krenn, 2007). They might have crystallized directly from a fluid as crystals lie within the rocks' foliation associated with hydrated phases (Fig. 3). Furthermore, in Fig. 4, the richest PbO monazites from mylonitic samples GD04-190 


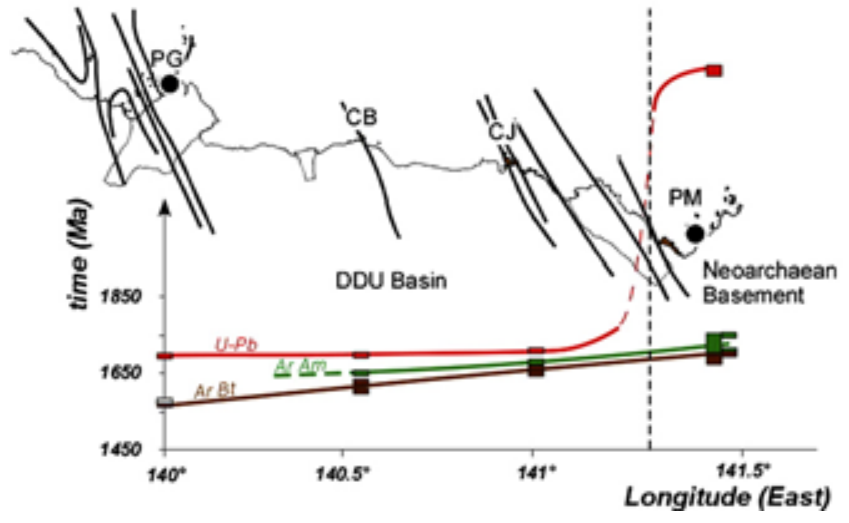

Fig. 9. Longitudinal time-temperature projection in the Dumont D'Urville basin and its eastern basement, sub-perpendicular to the regional foliation strike (black curves). Red, green, grey and brown boxes correspond to zircon or monazite $\mathrm{U}-\mathrm{Pb}$ (closure temperature $\sim 700^{\circ} \mathrm{C}$ ), Amphibole Argon $\left(\sim 550^{\circ} \mathrm{C}\right)$, Muscovite Argon $\left(\sim 450^{\circ} \mathrm{C}\right)$ and Biotite Argon $\left(\sim 350^{\circ} \mathrm{C}\right)$ ages respectively. Lines divergence from Port Martin to Point Géologie illustrates an exhumation gradient from east to west, with exhumation rates up to $0.2 \mathrm{~mm} \mathrm{yr}^{-1}$ in Cape Jules decreasing westward to $0.1 \mathrm{~mm} \mathrm{yr}^{-1}$. This exhumation gradient correlates with the deformation gradient from dome-shaped structures to the west to vertical shear zones to the east described by Pelletier et al. (2002). Abbreviations for localizations are the same than in Fig. 2. (For interpretation of the references to colour in this figure legend, the reader is referred to the web version of the article.)

and GD04-130 are above the $1.7 \mathrm{Ga}$ line. Other monazite analyses from these samples lie on the $1.7 \mathrm{Ga}$ curve for $\mathrm{ThO}_{2}{ }^{*}<4.5$ and 6.5 respectively, supporting age mixing and partial resetting during the $c a .1 .7 \mathrm{Ga}$ event. $\mathrm{Pb}$ loss cannot be directly inferred by the electron probe technique and would require isotopic analysis to be established. Carbonate bearing metapelites GD04-155 and retromorphosed granulite RPM03-37, associated with marbles and calc-silicates, record age inheritance at ca. $2090 \mathrm{Ma}$, supporting that the Moyes archipelago's metasediments belong to the Neoarchaean domain as they record a high-grade metamorphic imprint prior to $2.0 \mathrm{Ga}$.

As suggested by Oliver and Fanning (2002) in relation to Madigan Nunatak and new data from Cape Gray (GD04-190) or Watt Bay (GD04-130 and GD04-147), the $1.7 \mathrm{Ga}$ tectonic reactivation localized in shear zones marked by ultramylonites under low grade conditions is associated with fluid circulation (Fig. 3C-H, J and K). Here, it is evident that the transition zone between the granulite and the amphibolite subdomains may define a major rheological boundary within the Neoarchaean crust.

\subsubsection{The Paleoproterozoic basins}

In the Paleoproterozoic domain, published $\mathrm{U}-\mathrm{Pb}$ ages from Peucat et al. (1999a) for the Dumont D'Urville Basin migmatites range between $1712 \pm 7 \mathrm{Ma}$ (zircon from sample JJP98-6) and $1695 \pm 5$ Ma (monazite from sample OM110-1). These enable us to define the regional metamorphic peak at $1700 \pm 10 \mathrm{Ma}$ all over the basin.

\subsection{Significance of the ${ }^{40} \mathrm{Ar} /{ }^{39} \mathrm{Ar}$ data}

\subsubsection{The Neoarchaean granulite crust}

On the eastern margin of the TAC, within the Mertz shear zone, Di Vicenzo et al. (2007) have obtained ${ }^{40} \mathrm{Ar} /{ }^{39} \mathrm{Ar}$ laserprobe biotite ages ranging from $1492 \pm 11 \mathrm{Ma}$ to $1559 \pm 08 \mathrm{Ma}$ at the Corell Nunatak (in the amphibolitic crust along the Mertz Shear zone-Fig. 8A and B) and $1502 \pm 09 \mathrm{Ma}$ at the Aurora Peak (in granulite facies). We obtained biotite plateau ages in a sim- ilar range: $1509 \pm 03 \mathrm{Ma}$ at Stillwell Island and $1537 \pm 03 \mathrm{Ma}$ on Close Island. These results support the occurrence of a thermal event along the Mertz shear zone during the $\sim 1500-1550$ Ma time range.

In contrast, the much older biotite plateau age of $1702 \pm 03 \mathrm{Ma}$ (GD04-183) in the Cape Gray, tens of kilometres to the West, indicates that the $1500-1550 \mathrm{Ma}$ thermal overprinting or extensive fluid flow + deformation event is localized and not pervasive within the rest of the craton.

The biotite age from the Cape Pigeon shear zone sample (GD04$126)$ lies in between these two age groups. It is older ( $\sim 1612 \mathrm{Ma})$ than the $\sim 1.50-1.55 \mathrm{Ga}$ age range. This latter age is interpreted as being due to excess ${ }^{40} \mathrm{Ar}$ as biotite can be a sink of excess ${ }^{40} \mathrm{Ar}$ during fluid circulation within a shear zone (e.g., Arnaud and Kelley, 1995). In the Cape Pigeon case, excess ${ }^{40} \mathrm{Ar}$ is not apparent from the data plots alone, as the biotite ${ }^{40} \mathrm{Ar} /{ }^{39} \mathrm{Ar}$ spectra show flat plateau ages, and the inverse isochron plots preserve an atmospheric initial ratio of $\left({ }^{36} \mathrm{Ar} /{ }^{40} \mathrm{Ar}\right)_{0}$. However, even in cases of flat Ar spectra, biotite dating has shown to yield unrealistic geological ages especially in cases of mylonitic deformation (Leloup et al., 2005; Rolland et al., 2007, 2008). As the biotite sample GD 04-126 was sampled in a mylonite, it is likely that its slightly older age may be due to some excess ${ }^{40} \mathrm{Ar}$, although this excess component is not visible from the ${ }^{36} \mathrm{Ar} /{ }^{40} \mathrm{Ar}$ vs ${ }^{39} \mathrm{Ar} /{ }^{40} \mathrm{Ar}$ isochron plots. This excess component may be inherited from $1.7 \mathrm{Ga}$ relic minerals.

In contrast to the biotite ${ }^{40} \mathrm{Ar} /{ }^{39} \mathrm{Ar}$ data, which show plateau or mini-plateau ages in almost all samples, amphibole ${ }^{40} \mathrm{Ar} /{ }^{39} \mathrm{Ar}$ data from Di Vicenzo et al. (2007) show highly disturbed spectra. Indeed, their ${ }^{40} \mathrm{Ar} /{ }^{39} \mathrm{Ar}$ laserprobe apparent ages range from $1722 \mathrm{Ma}$ to 2402 Ma. Di Vincenzo et al. interpreted the variations older than $1.7 \mathrm{Ga}$ as reflecting the presence of excess ${ }^{40} \mathrm{Ar}$ in the analysed samples, which could be ascribed to other mineral inclusions such as clinopyroxene. They further ascribe the $\sim 1.7 \mathrm{Ga}$ ages as reflecting a "real" tectonometamorphic event. Moreover, the 1.50-1.55 Ga event has not totally reset the ${ }^{40} \mathrm{Ar} /{ }^{39} \mathrm{Ar}$ amphibole chronometer as older ages of $1.7 \mathrm{Ga}$ and $>1.9 \mathrm{Ga}$ are obtained (Di Vincenzo et al., 2007). Thus this late $1.50-1.55 \mathrm{Ga}$ thermal resetting seems to have occurred under low temperature conditions, not exceeding amphibole closure temperature $\left(<500^{\circ} \mathrm{C}\right)$.

\subsubsection{The Neoarchaean amphibolite crust}

Biotite samples exhibit plateau ages between $1678 \pm 03 \mathrm{Ma}$ (Port Martin) and $1700 \pm 03 \mathrm{Ma}$ (Cap de la Découverte). Some samples show only a mini-plateau age in agreement with other plateau ages. This is due to a small disturbance in the low temperature part of the spectra (Port Martin and Cap de la Découverte samples). We interpret this low temperature disturbance as resulting from a short-lived thermal event close to the closure temperature of the Ar system in biotite $\left(300-350^{\circ} \mathrm{C}-\right.$ Harrison et al., 1985). This shortlived event may result from late fluid flow along the shear zones and is likely to be contemporaneous the $\sim 1500$ Ma event as it is well developed close to the MSZ.

\subsubsection{The Paleoproterozoic basins}

In the Dumont D'Urville Basin, all biotite samples show plateau ages (Fig. 7). The plateau ages range between $1567.2 \pm 2.2 \mathrm{Ma}$ (Pointe Géologie) and 1690.7 $\pm 7.0 \mathrm{Ma}$ (Cap Jules). Furthermore, the ${ }^{40} \mathrm{Ar} /{ }^{39} \mathrm{Ar}$ data evidence a space and time gradient, with decreasing ages from East to West, as already noted for amphibole ages. In contrast, $\mathrm{U}-\mathrm{Pb}$ ages for both Pointe Géologie and Cap Jules are similar (data from Peucat et al., 1999a; Pelletier et al., 2002 and unpublished data). Consequently, we interpret the lateral ${ }^{40} \mathrm{Ar} /{ }^{39} \mathrm{Ar}$ biotite age gradient as reflecting a variation in the exhumation rate. According to the $P-T$ estimates of Pelletier et al. (2002), a geothermal gradient of $35^{\circ} \mathrm{C} \mathrm{km}^{-1}$ is inferred and for an average crustal 

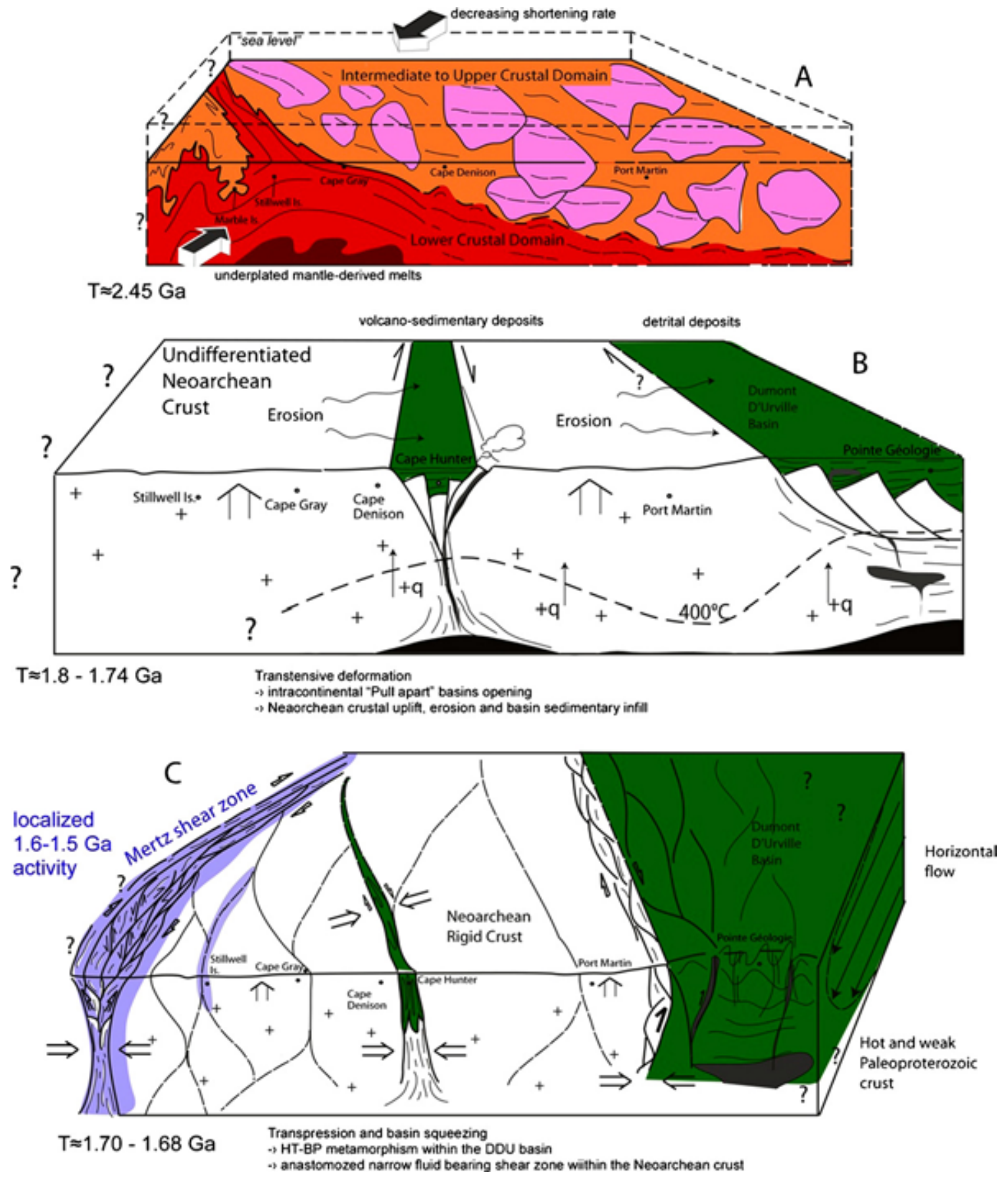

Fig. 10. Geodynamic evolution sketch. Geodynamic evolution sketch of the TAC in Late Archaean to Proterozoic times (view is towards the south). (A) The main Eastern TAC orogenic event major occurred at $2.45 \mathrm{Ga}$ in a NE-SW shortening context. This tectono-thermal event reactivated the $2.8-2.6 \mathrm{Ga}$ juvenile crust of the TAC. In red, the deep crust is metamorphosed under granulite facies metamorphism associated with mafic underplating (brown colour). This is directly followed by retrogression under amphibolite facies conditions and important partial melting and granodioritic magmas emplacement around 2450 Ma. Important lateral flow of the crust favored thinning and acquisition of a dome-shaped structure exhumating the granulitic crustal root. (B) Continuous uplift of this Late Archaean crust is allowed by mechanical erosion and trans-current basins opening (Cape Hunter and Dumont D'Urville, in green). These processes favored recycling Neoarchaean material before 1.76 Ga. Basins were filled with detrital material from the surrounding basement in addition to some newly formed magmas. (C) Tectonic convergence and basins closure occurred around 1.7 Ga. Basins were squeezed. The DDU basin records HT-LP metamorphism associated with anatexis. Dome structures developed in the central part of the basin and vertical shear zones concentrated to the east, at the contact with the cold and strong Neoarchaean crust. This latter domain acted as a rigid block and developed narrow anastomosed shear zones acting as a plumbing system for fluid circulations. Deformation along the Mertz Shear zone (purple colour) seems to initiate at c. 1.62 Ga, and to remain active until around $1.51 \mathrm{Ga}$ as shown by $\mathrm{Ar}-\mathrm{Ar}$ data. (For interpretation of the references to colour in this figure legend, the reader is referred to the web version of the article.)

density of 2.7, we estimate slow and slightly dissimilar exhumation rates of $0.2 \pm 0.5 \mathrm{~mm} \mathrm{yr}^{-1}$ in the east and $0.1 \pm 0.5 \mathrm{~mm} \mathrm{yr}^{-1}$ in the west.

Muscovite ages are similar within error in the Cape Hunter phyllites (maximum age of $1585 \pm 16 \mathrm{Ma}$ ) and in the Pointe Géologie migmatites (1576.8 $\pm 3.6 \mathrm{Ma}$, mini-plateau age). As Pointe Géologie muscovite is $\sim 9$ Ma older than biotite from the same sample, it suggests a cooling rate of $6 \pm 2{ }^{\circ} \mathrm{CMa}^{-1}$ estimated from the $T-t$ history based on $\mathrm{U}-\mathrm{Pb}$ ages on monazites and ${ }^{40} \mathrm{Ar} /{ }^{39} \mathrm{Ar}$ ages on biotites (and closure temperatures by Harrison et al., 1985). 


\subsection{Tectonic history}

According to the published structural data (Ménot et al., 2005; Duclaux et al., 2007) and geochronological data (Oliver and Fanning, 1997; Peucat et al., 1999b; Di Vincenzo et al., 2007; this study), we put forward a tectonic history of the TAC from the Neoarchaean to the Mesoproterozoic. Further, the tectonic evolution, inferred from structural and geochronological data is summarized in Fig. 10 and can be separated into four tectonic phases:

(1) The Neoarchaean phase: A 2.6-2.8 Ga juvenile continental crust is metamorphosed under HT granulite to amphibolite facies conditions at around $2.47 \mathrm{Ga}$. In the eastern TAC, a deep crustal granulite domain is exhumed in a dome-shaped structure and deformation is dominated by horizontal constriction. Evidence for this vertical motions is the occurrence of narrow upper-crustal sedimentary derived rock pods (i.e. in the Moyes Archipelago) that have recrystallized under granulite facies conditions (Fig. 10A). These observations are in agreement with the models of Cagnard et al. (2006), suggesting both vertical and horizontal ductile flow of the weak and warm lower crust. Such weakening of the lower crust can be explained by the underplating of large volumes of mantle-derived melts as proposed within the Dharwar craton by Chardon et al. (2002). Such underplating below the eastern TAC is evidenced by the presence of numerous mafic dikes and sills. The underplated mafic melts may have induced a high thermal gradient and lead to relative uplift of the lower crust leading to crustal scale tilting of the Neoarchaean domain observed from east to west (Fig. 10A). This is supported by the younging of $\mathrm{U}-\mathrm{Pb}$ ages and the occurrence of upper crustal granodioritic rocks to the west. Therefore, the main structure of the Neoarchaean domain of the TAC appears to be related to this $2.5-2.4 \mathrm{Ga}$ tectonometamorphic event.

(2) The opening of the intracontinental Cape Hunter and Dumont D'Urville basins can be related to a Paleoproterozoic extensional phase (Fig. 10B). These basins opened synchronously and the minimum age of sediment deposition is constrained by the youngest detrital core zircons ages at $1.76 \mathrm{G}$ and $1.72 \mathrm{G}$ dated in the Cape Hunter phyllites and the DDU migmatites respectively (Oliver and Fanning, 1997; Peucat et al., 1999a). The protolith of the DDU gneisses (Monnier et al., 1996) indicates a sedimentary origin that might correspond to a mature rift system with strong erosion and transport and to a subordinate silica-rich igneous contribution (Peucat et al., 1999a). A comparable origin was inferred by Oliver and Fanning (1997) for the Cape Hunter metasediments. The narrow shape of the Cape Hunter Basin is suggested by its extension to the Price Island phyllites, in the South Australian Gawler craton (Oliver and Fanning, 1997). Such a geometry fits well with a transtensive depositional context. In contrast, the Dumont D'Urville basin seems to represent a wider structure with regard to its very thick sediment pile and its regional extension.

(3) Following this stage, a Paleoproterozoic transpressive phase is identified by HT metamorphism, crustal anatexis and mantle derived magmatism (Fig. 8F) within the DDU basin (Pointe Géologie area, Peucat et al., 1999a; Pelletier et al., 2002) and new ${ }^{40} \mathrm{Ar} /{ }^{39} \mathrm{Ar}$ ages obtained essentially in the intermediate to upper crustal Neoarchaean domain and within the basins (Fig. 10C).

In the Neoarchaean domain, this $1.7 \mathrm{Ga}$ tectono-metamorphic event is indicated by an anastomosing shear zone network indicating a global E-W to NE-SW shortening event with slight strike-slip component and recrystallization associated with fluid circulation in decimetre to metre-scale shear zones. This tectono-metamorphic event is discrete in the Neoarchaean basement, where it only reactivates previous transcurrent structures. Ca. $2.5 \mathrm{Ga} \mathrm{U}-\mathrm{Pb}$ ages are well preserved and have only been reset in highly strained zones due to intense strain overprinting in the greenschist facies conditions with high fluid/rock ratio. Partial to total resetting of the $\mathrm{Ar} / \mathrm{Ar}$ amphibole chronometer (Di Vincenzo et al., 2007) implies that the peak temperature slightly exceeded $550^{\circ} \mathrm{C}$ (Villa, 1998) inside the Neoarchaean domain.

Along the N30 Mertz shear zone, deformation is mainly coaxial, associated with conjugate sinistral N140 shear bands. Neoarchaean granulite tectonic lenses were observed in the field within the shear zone suggesting a positive flower structure with exhumation of large rigid blocks in the centre of the shear zone. Outside of the granulite lenses, deformation occurred at the ductile/brittle transition $\left(350-400^{\circ} \mathrm{C}\right)$ as evidenced by biotite/chlorite recrystallization and the cataclastic fabric of quartz and feldspar along shear zones.

In the Paleoproterozoic basins, The Cape Hunter phyllites display upright folding with a vertical foliation and sub-vertical fold axes. This is consistent with horizontal shortening during basin closure.

In the Dumont D'Urville basin, Pelletier et al. (2002), and Gapais et al. (2008) describe a deformation gradient from dome-shaped structures to the west to vertical shear zones to the east. $\mathrm{U}-\mathrm{Pb}$ ages date the metamorphic peak conditions at $1.69 \mathrm{Ga}$ for the entire Dumont D'Urville basin. In contrast, ${ }^{40} \mathrm{Ar} /{ }^{39} \mathrm{Ar}$ amphibole and biotite ages show a W-E gradient with increasing ages toward the basin's eastern rim. Within the basin, in the Pointe Géologie area, the exhumation rate is low at $0.1 \mathrm{~mm} \mathrm{yr}^{-1}$ and increases eastward up to $0.2 \mathrm{~mm} \mathrm{yr}^{-1}$, in the Cap Jules area (Fig. 9). These contrasting exhumation rates are consistent with the deformation gradient. In fact, in a transpressive context, vertical motions are partitioned and increase at the vicinity of the main shear zone (Fossen and Tikoff, 1998; Cruden et al., 2006; Cagnard et al., 2006). In comparison to modern orogens, such tectonic uplift rates are one order of magnitude lower. For instance uplift rates of $3 \mathrm{~mm} \mathrm{yr}^{-1}$ are estimated in the high Karakoram range and about $1 \mathrm{~mm} \mathrm{yr}^{-1}$ in the French Alps (Rolland et al., 2001, 2007). This could be explained either by a slower convergence rate, or a different deformation mode of the warm lithosphere. In the absence of any estimate of paleoconvergence rates, we cannot discuss the former hypothesis. Nevertheless, horizontal flow and tangential movements dominate vertical motions within a warm lithosphere and are the key mechanisms that control the large-scale deformation style (Rey and Houseman, 2006; Duclaux et al., 2007; Gapais et al., 2008).

(4) A 1550-1500 Ma event is solely recorded in the Neoarchaean basement by complete resetting of ${ }^{40} \mathrm{Ar} /{ }^{39} \mathrm{Ar}$ biotite and partial resetting of ${ }^{40} \mathrm{Ar} /{ }^{39} \mathrm{Ar}$ amphibole ages within a restricted area of $20 \mathrm{~km}$ wide along the Mertz Shear zone (from Correll Mount to Stillwell Island). Direct age measurements undertaken on the Mertz shear zone samples record a last geochronological event at $1509 \mathrm{Ma}$ (Di Vicenzo et al., 2007), corresponding to greenschist grade biotite and chlorite recrystallization. The significance of this $\sim 1.5 \mathrm{Ga}$ event is still not clearly established. Thermal overprinting during this event is not pervasive within the entire Neoarchean and Paleoproterozoic crystalline basement. It is shown to affect mainly the Mertz high-strain zone, where mylonitic deformation and associated upper greenschist facies metamorphism have occurred. Have the Ar system been reset only where extensive fluid flow was focussed i.e. in the main shear zone, while a thermal event of $\mathrm{ca} .300^{\circ} \mathrm{C}$ occurred in the whole region? Or does this age group represent a thermal event restricted to the eastern border of the region? From our observations, it is still difficult to answer 
this question. However, we can note from our studied sample (i.e. GD04-120) that a static recrystallization of biotite has occurred even in the shear zone core. Thus, we interpret this event as a phase of recrystallization due to intense fluid circulation that mimics some thermal overprinting. At the regional scale, this event is contemporaneous with the activation of major shear zones within the Gawler Craton in South Australia (Swain et al., 2005). In this global context, the Mertz Shear zone may act as a major plumbing system for fluid circulation at around 1550-1500 Ma. Furthermore, the Mertz shear zone is a major boundary between East and West Antarctica, and further reworking may possibly have occurred later under very low grade and probably brittle conditions.

\section{Conclusions}

The combination of structural and geochronological studies allows us to propose a detailed geological scenario for the TAC, from the Neoarchaean to the Mesoproterozoic.

(1) During the Archaean period: following a period of crustal generation prior to $2.6 \mathrm{Ga}$, the Neoarchaean domain underwent a major tectono-metamorphic event at ca. $2.44 \mathrm{Ga}$. Retrogression from granulite to amphibolite occurred within a short time period before $2.44 \mathrm{Ga}$. Exhumation of lower granulitic crust occurred within a dome-shaped structure and juxtaposition with the upper to intermediate subdomain took place during this orogenic episode (Ménot et al., 2005; Duclaux et al., 2007).

(2) During the Paleoproterozoic period: basin opening occurred in a transtensive tectonic context within and above the already exhumed Archaean basement, rapidly followed by basin closure at ca. $1.7 \mathrm{Ga}$. Within the already cooled Archaean domain, deformation at the ductile/brittle transition is localized in metre-scale anastomozed shear zones. The Mertz shear Zone is active during this period and featured by intense tectonic reactivation. In the DDU basin, the HT deformation is more penetrative at hectometre-scale. Despite slightly contrasted uplift rates between the rim and the centre of the basin, exhumation rates remain low $\left(0.1-0.2 \mathrm{~mm} \mathrm{yr}^{-1}\right)$ reflecting massive horizontal flow in the Paleoproterozoic crust.

(3) During the Mesoproterozoic period: partial resetting occurred within a narrow zone along the Mertz Shear zone which acts as passive plumbing system for fluid transfers.

Usually, in general models of continent generation, terranes amalgamation are discussed in order to explain crustal growth processes. In the TAC case, Paleoproterozoic basins seem to have opened directly on the Archaean basement and recycled this older crust. Consequently, the TAC is a good example of intracontinental evolution without any evidence of subduction, suture zone and oceanic accretionary collage. Whether general changes in the deformation style occurred at this time period on Earth, they cannot be proven by only looking at this one region as the tectonic history and deformation styles are intimately interlinked with the prevailing $P-T$ conditions of the crustal regime now exposed for us to examine.

\section{Acknowledgements}

This work has been conducted with help and the logistics provided by the French Polar Institute (IPEV) in the frame of the GEOLETA program. Additional funding for analyses was provided by the CNRS (DYETI) program entitled "Deformation of anomalously hot Lithospheres". We wish to thank the support of the technical staff in Saint-Etienne, Lyon and Nice universities, who assisted with sample preparation and data acquisition. We thank G. Féraud for his help with the ${ }^{40} \mathrm{Ar} /{ }^{39} \mathrm{Ar}$ analysis. C. Clark and S. Harley are warmly thank for their helpful suggestions, which improved the quality of the manuscript. GD thanks N. Lazima for improving the English of the manuscript.

\section{Appendix A. Analytical procedure and data processing (Gongalves et al., 2004)}

The theoretical basis and associated statistical treatment of data follow the analytical procedure detailed by Montel et al. (1996). Measurements were performed on a Cameca SX100 electron microprobe at the Laboratoire Magmas et Volcans, Clermont-Ferrand, and on a Camebax electron microproble at the Laboratoire des Sciences de la Terre, Lyon.

Analytical conditions include an accelerating voltage of $15 \mathrm{kV}$ and a beam current of $150 \mathrm{nA}$. $U$ and Th were analysed successively with a PET crystal on the same wavelength-dispersive spectrometer with a counting time of $225 \mathrm{~s}$ and $75 \mathrm{~s}$ on peak, respectively. $\mathrm{Pb}$ was analysed with an LPET crystal using a 300 s counting time on peak. $\mathrm{P}, \mathrm{Ca}, \mathrm{Si}$ and $\mathrm{Y}$ were analysed successively with a PET crystal on the same spectrometer with a $30 \mathrm{~s}$ counting time for $\mathrm{P}$ and $\mathrm{Ca}$, and $90 \mathrm{~s}$ for Si and Y. Light rare earth elements (LREE; La, Ce, Pr, Nd, Sm and Gd) were analysed using an LIF crystal with counting time of $30 \mathrm{~s}$ for La and Ce, $45 \mathrm{~s}$ for Pr and Nd, and $60 \mathrm{~s}$ for Sm and Gd. Counting time for the background corresponds to half of peak time for each element, on both sides of the peak. X-ray lines and background offsets, which were not always symmetrical with respect to the peak, were selected to minimize the X-ray line interferences. X-ray lines selected were: $\mathrm{K} \alpha$ for $\mathrm{P}, \mathrm{Ca}$ and $\mathrm{Si}$; $\mathrm{L} \alpha$ for $\mathrm{Y}$, La and $\mathrm{Ce}$; $\mathrm{L} \beta$ for $\mathrm{Pr}, \mathrm{Nd}, \mathrm{Sm}$ and $\mathrm{Gd} ; \mathrm{M} \alpha$ for Th and $\mathrm{Pb} ; \mathrm{M} \beta$ for $\mathrm{U}$. The $\mathrm{Pb} \mathrm{M} \alpha-\mathrm{Y} \mathrm{L} \gamma$ overlap correction factor was 0.0018 . The $\mathrm{U} M \beta-\mathrm{Th}$ M $\gamma$ overlap was not corrected.

Standards used were $\mathrm{UO}_{2}$ and $\mathrm{ThO}_{2}$ for $\mathrm{U}$ and Th, apatite for $\mathrm{Ca}$, zircon for $\mathrm{Si}$, and synthetic phosphates for the REE, $\mathrm{P}$ and $\mathrm{Y}\left(\mathrm{LaPO}_{4}\right.$, $\mathrm{CePO}_{4}$, etc.). For Pb, a synthetic glass was used for calibration. Beam current used for standards was $100 \mathrm{nA}$. Counting time was $50 \mathrm{~s}$ on peak and $20 \mathrm{~s}$ on background for $\mathrm{UO}_{2}$ and $\mathrm{ThO}_{2}$, and $300 \mathrm{~s}$ on peak and $100 \mathrm{~s}$ on background for PbO. Counting times for LREE and other elements (Ca, Si, P and Y) were $80 \mathrm{~s}$ and 40 s respectively on peak, and $20 \mathrm{~s}$ and $10 \mathrm{~s}$ respectively on background. Errors in $\mathrm{U}$, Th and $\mathrm{Pb}$ contents and detection limits were calculated using the procedure of Ancey et al. (1978).

Individual ages, which are referred to as measurements, were calculated from the $\mathrm{U}, \mathrm{Th}$ and $\mathrm{Pb}$ concentrations. The $2 \sigma$ errors given on measurements depend on $\mathrm{U}$, Th and $\mathrm{Pb}$ contents and were calculated by propagating the uncertainties in these elements (at the 95\% confidence level) into the decay equation. Samples ages and associated errors (with 95\% confidence level) were calculated by averaging the individual measurements assuming that they belong to a single population. A least-squares modelling approach was applied to the whole population of measurements to identify multiple populations (Montel et al., 1996). The quality of the modelling is assessed from the mean square of weighted deviates (MSWD). The whole measurement population is graphically depicted in weighted histograms, where each measurement and its uncertainty are represented by bell-shaped probability curves.

A study by Jercinovic and Williams (2005) has demonstrated that inaccurate background subtraction and interference correction can lead to dramatic errors of $50 \mathrm{Ma}$ or more in EMP dating when concentrations approach the trace element range. Because our background was estimated via a simple two-point linear interpola- 
tion and $\mathrm{U} \mathrm{M} \beta-\mathrm{Th} \mathrm{M} \gamma$ interference was not considered, variations below $50 \mathrm{Ma}$ in chemical ages have not been over-interpreted in this study.

\section{Appendix B. Detailed presentation of the monazite dating results}

In the following paragraph, we provide details of monazites age modelling by location, from East to West.

Along the MSZ at Aurora Peak, tiny monazites within shear bands of Opx-Pl-Qtz mylonites samples RPM98-119 and RPM98$124 \mathrm{~b}$ display one statistical population age at $1619 \pm 48 \mathrm{Ma}$ (MSWD $0.97, n=10$ ), defining the peak of tectonic activity, and older inheritance with a bulk age at $1890 \pm 52 \mathrm{Ma}(n=4)$.

On Close Island, large monazites from the migmatite gneiss sample GD04-174 record a single monazite population age at $c a$. $2530 \mathrm{Ma}$ (A. Fernandez, pers. com.).

Further west, on the Hodgeman Archipelago, granulitic migmatite gneisses GD04-162 and GD04-160a display 2 statistical population ages from large monazites included in garnet and feldspar, at $2477 \pm 22 \mathrm{Ma}$ (MSWD 2.66, $n=15$ ) and $2282 \pm 40 \mathrm{Ma}$ (MSWD 0.7, $n=8$ ). The first population age is interpreted to reflect the time of the granulite facies metamorphic peak, and the latter may relate to some $\mathrm{Th}-\mathrm{U}-\mathrm{Pb}$ system partial resetting or late fluid circulation and rejuvenation of monazites by $\mathrm{Pb}$ loss.

Within the Watt Bay, samples from two locations have been dated. Small monazites from Al-rich metapelites GD04-155 and RPM03-34, associated with marbles and calc-silicates, represent one poorly constrain population at $1755 \pm 54 \mathrm{Ma}(\mathrm{MSWD} 2.37, n=4)$ and record some older inheritance at $2094 \pm 180 \mathrm{Ma}$ (MSWD 0.09, $n=2$ ). As the first age is interpreted as reflecting dynamic recrystallization and $\mathrm{CO}_{2}$ bearing fluid circulation during a tectono-thermal event, the second may just represent some partially resetted relicts from an earlier event.

On C Island, we selected three samples for their interesting textures and meaningful field relationships. A hydrated mylonitic shear zone (GD04-147) dated at $1696 \pm 44 \mathrm{Ma}$ (MSWD 0.76, $n=6$ ) cross-cut an istotropic hectometric tonalitic body (GD04-149) dated at $2433 \pm 34 \mathrm{Ma}$ (MSWD $1.18, n=11$ ) that includes a foliated granulitic mafic xenoliths (GD04-148) dated at $2629 \pm 22 \mathrm{Ma}$ (MSWD 2.50, $n=14$ ).

On the Cape Pigeon, two orthogneissic samples, GD04-130 and GD04-133, in the vicinity of a steep shear zone described in Ménot et al. (2005), record two statistical populations ages. The first is well defined at $1697 \pm 44 \mathrm{Ma}$ (MSWD 0.37, $n=11$ ), and the second is defined at $1869 \pm 70 \mathrm{Ma}$ (MSWD $1.2, n=4$ ). The ca. $1700 \mathrm{Ma}$ age might correspond to the reactivation and dynamic recrystallization along the shear zone, whereas the older age might correspond to partial resetting of an older age or to an earlier tectonic activity but has to be taken with care regarding the low numbers of analyses.

On Stillwell Island, an intrusive granite body including relictual garnets records two monazite population ages at $2468 \pm 44 \mathrm{Ma}$ (MSWD 0.7, $n=6$ ) from monazites included in the qtz-pl matrix and $2586 \pm 38 \mathrm{Ma}$ (MSWD 0.47, $n=9$ ) from monazites included in garnets.

Some tens of kilometres more to the west on the boundary of the deep subdomain, on Fletcher C Island a fluid rich mylonite (GD04190) displays 2 population ages at $1897 \pm 28 \mathrm{Ma}(\mathrm{MSWD} 1.59, n=10)$ and $1712 \pm 34 \mathrm{Ma}$ (MSWD 2.81, $n=6$ ).

\section{References}

Alexandrov, P., Ruffet, G., Cheilletz, A., 2002. Muscovite recrystallization and saddleshaped ${ }^{40} \mathrm{Ar} /{ }^{39} \mathrm{Ar}$ age spectra: example from the Blond granite (Massif Central, France). Geochimica et Cosmochimica Acta 66 (10), 1793-1807.
Ancey, M., Bastenaire, F., Tixier, R., 1978. Application des méthodes statistiques en microanalyse. In: Maurice, F., Menyand, L., Tixier, R. (Eds.), Microanalyse, Microscopie Électronique à Balayage. Les éditions du physicien, Orsay, pp. 323-347.

Arnaud, N.O., Kelley, S.P., 1995. Evidence for excess argon during high pressure metamorphism in the Dora Maira Massif (Western Alps, Italy), using an ultra-violet laser ablation microprobe ${ }^{40} \mathrm{Ar}-{ }^{39} \mathrm{Ar}$ technique. Contributions to Mineralogy and Petrology 121, 1-11.

Cagnard, F., Durrieu, N., Gapais, D., Brun, J.P., Ehlers, C., 2006. Crustal thickening and lateral flow during compression of hot lithospheres, with particular reference to precambrian times. Terra Nova 18 (1), 72-78.

Castonguay, S., Ruffet, G., Tremblay, A., Féraud, G., 2001. Tectonometamorphic evolution of the Southern Quebec Appalachians: ${ }^{40} \mathrm{Ar} /{ }^{39} \mathrm{Ar}$ evidence for Middle Ordovician crustal thickening and Silurian-Early Devonian exhumation of the internal Humber zone. Bulletin of the Geological Society of America 113 (1), 144-160.

Chardon, D., Peucat, J.J., Jayananda, M., Choukroune, P., Fanning, C.M., 2002. Archean granite-greenstone tectonics at Kolar (South India): interplay of diapirism and bulk inho-mogeneous contraction during juvenile magmatic accretion. Tectonics 21 (3), 7-1-7-17.

Cheilletz, A., Ruffet, G., Marignac, C., Kolli, O., Gasquet, D., Feraud, G., Bouillin, J.P., 1999. ${ }^{40} \mathrm{Ar} /{ }^{39} \mathrm{Ar}$ dating of shear zones in the Variscan basement of Greater Kabylia (Algeria). Evidence of an Eo-Alpine event at $128 \mathrm{Ma}$ (Hauterivian-Barremian boundary): geodynamic consequences. Tectonophysics 306 (1), 97-116.

Collins, A.S., Reddy, S.M., Buchan, C., Mruma, A., 2004. Temporal constraints on Palaeoproterozoic eclogite formation and exhumation (Usagaran Orogen, Tanzania). Earth and Planetary Science Letters 224 (1-2), 177-194.

Cruden, A.R., Nasseri, M.H.B., Pysklywec, R., 2006. Surface topography and internal strain variation in wide hot orogens from three-dimensional analogue and twodimensional numerical vice models. Geological Society Special Publication 253, 79-104.

Di Vincenzo, G., Talarico, F., Kleinschmidt, G., 2007. An ${ }^{40} \mathrm{Ar}-{ }^{39} \mathrm{Ar}$ investigation of the Mertz Glacier area (George V Land, Antarctica): implications for the Ross Orogen-East Antarctic Craton relationship and Gondwana reconstruction. Precambrian Research 152, 93-118.

Duclaux, G., Rey, P., Guillot, S., Ménot, R.P., 2007. Orogen-parallel flow during continental convergence: numerical experiments and Archean field examples. Geology 35 (8), 715-718.

Duclaux, G., 2007. Comportement mécanique des lithosphères continentals chaudes - Evolutions des cratons Néoarchéens et Paléoprotérozoïques de Terre Adélie (Antarctique Est) et du Gawler (South Australia). Ph.D. Thesis, Université Jean Monnet \& The University of Sydney. Available from: <http://tel.archivesouvertes.fr/index.php?halsid=2gl9idaauh94pqnnh8djb9j544\&view_this_doc=tel00206311\&version $=1>$.

Fanning, C.M., Daly, S.J., Bennett, V.C., Ménot, R.P., Peucat, J.J., Oliver, R.L., 1995. The "Mawson Block": once contiguous Archean to Proterozoic crust in the East Antarctic Shield and Gawler Craton, Australia. In: VII International Symposium on Antartic Earth Sciences, 10-15/09/1995, Sienna, Italy.

Fanning, C.M., Ménot, R.P., Peucat, J.J., Pelletier, A., 2002. A closer examination of the direct links between southern Australia and Terre Adélie and George V Land. In: Preiss, V.P. (Ed.), Geosciences 2002, Expanding Horizons. Abstracts of the 16th Australian Geological Conference, vol. 67. Adelaide, p. 224.

Fanning, C.M., Peucat, J.J., Ménot, R.P., 2003. Whither the Mawson continent? 9th ISAES, Potsdam, Abstract.

Finger, F., Krenn, E., 2007. Three metamorphic monazite generations in a highpressure rock from the Bohemian Massif and the potentially important role of apatite in stimulating polyphase monazite growth along PT loop. Lithos 95, 103-115, doi:10.1016/j.lithos.2006.06.003.

Fitzsimons, I.C.W., 2000. A review of tectonic events in the East Antarctic shield and their implications for Gondwana and earlier Supercontinents. Journal of African Earth Sciences 31 (1), 3-23.

Fitzsimons, I.C.W., 2003. Proterozoic basement provinces of southern and southwestern Australia and their correlation with Antarctica. In: Yoshida, M., Windley, B.F., Dasgupta, S. (Eds.), Proterozoic East Gondwana: Supercontinent Assembly and Breakup, vol. 206. Geological Society, Special Publications, London, pp. 93-130

Fossen, H., Tikoff, B., 1998. Extended models of transpression and transtension, and application to tectonic settings. Geological Society Special Publication (135), 15-33.

Gapais, D., Pelletier, A., Menot, R.P., Peucat,J.J., 2008. Paleoproterozoic tectonics in the Terre Adelie Craton (East Antarctica). Precambrian Research 162 (3-4), 531-539.

Goncalves, P., Nicollet, C., Montel, J.M., 2004. Petrology and in situ U-Th-Pb monazite geochronology of ultrahigh-temperature metamorphism from the Andriamena mafic unit, north-central Madagascar. Significance of a petrographical $P-T$ path in a polymetamorphic context. Journal of Petrology 45, 1923-1957.

Hamilton, W., 1998. Archean tectonics and magmatism. International Geology Review 40 (1), 1-39.

Harrison, T.M., Duncan, I., Mc Dougall, I., 1985. Diffusion of ${ }^{40} \mathrm{Ar}$ in biotite: temperature, pressure and compositional effects. Geochimica et Cosmochimica Acta 49, 2461-2468.

Jercinovic, M.J., Williams, M.L., 2005. Analytical perils (and progress) in electron microprobe trace element analysis applied to geochronology: background acquisition interferences, and beam irradiation effects. Am. Mineral. 9, 526546.

Jourdan, F., Verati, C., Feraud, G., 2006. Intercalibration of the $\mathrm{Hb} 3 \mathrm{gr}{ }^{40} \mathrm{Ar} /{ }^{39} \mathrm{Ar}$ dating standard. Chemical Geology 231 (3), 177-189. 
Leloup, P.H., Arnaud, N., Sobel, E.R., Lacassin, R., 2005. Alpine thermal and structural evolution of the highest external crystalline massif: The Mont Blanc. Tectonics 24, TC4002, doi:10.1029/2004TC001676.

Ménot, R.P., Peucat, J.J., Pelletier, A., Fanning, M., 1999. New constrains on the Archean - Proterozoic evolution of the Terre Adélie - George V Land, East Antartica. EUC 10, Strasbourg, March 28-Apri1 1999. Abstract vol. 122

Ménot, R.P., Pêcher, A., Rolland, Y., Peucat, J.J., Pelletier, A., Duclaux, G., Guillot, S. 2005. Structural setting of the Neoarchean terrains in the Commonwealth Bay Area $\left(143-145^{\circ}\right.$ E), Terre Adélie Craton, East Antarctica. Gondwana Research 8, $1-9$.

Ménot, R.P., Duclaux, G., Peucat, J.J., Rolland, Y., Guillot, S., Fanning, M., Bascou, J., Gapais, D., Pêcher, A., 2007. Geology of the Terre Adélie Craton $\left(135-146^{\circ} \mathrm{E}\right)$ In: Cooper, A.K., Raymond, C.R., et al. (Eds.) Antarctica: a Keystone in a Changing World - Online Proceedings of the 10th ISAES, USGS Open-File Report 2007-1047, Short Research Paper 048, 5 pp., doi:10.3133/of2007-1047.srp048.

Monnier, O., 1995. Le socle protérozoique de Terre Adélie (Antarctique Est): son évolution tectono-métamorphique et sa place dans dans les reconstitutions du Proto-Gondwana. Unpublished PhD thesis, Université de Saint Etienne, 321 pp.

Monnier, O., Ménot, R.P., Peucat, J.J., Fanning, M., Giret, A., 1996. Actualisation des données géologiques sur Terre Adélie (Antarctique Est): mise en évidence d'un collage tectonique au Paléoprotérozoïque, Comptes Rendus De L Academie Des Sciences, Paris 322, IIa, 55-62.

Montel, J.M., Foret, S., Veschambre, M., Nicollet, C., Provost, A., 1996. Electron microprobe dating of monazite. Chemical Geology 131, 37-53.

Oliver, R.L., Fanning, C.M., 1997. Australia and Antarctica: Precise correlations of Palaeoproterozoic terrains. In: Ricci, C.A. (Ed.), The Antarctic Region: Geological Evolution and Processes. Terra Antartica Publication, Sienna, pp. 163-172.

Oliver, R.L., Fanning, C.M., 2002. Proterozoic geology east and southeast of Commonwealth Bay, George $\mathrm{V}$ land, Antarctica, and its relationship to that of adjacent Gondwana terranes. In: Gamble, J.A., Skinner, D.N.B., Henry, S. (Eds.), Antarctic at the Close of a Millennium, The Royal Society of New Zealand Bulletin 35, 51-58.

Pelletier, A., Gapais, D., Ménot, R.P., Guiraud, M., 1999. The 1.7 Ga tectonic and metamorphic event in the Terre Adélie Craton (East Antarctica). In: 8th International Symposium on Antarctic Earth Sciences, Wellington, NZ, July, Abstract vol. 239.

Pelletier, A., Ménot, R.P., Gapais, D., Peucat J.J., 2001. Late Archaen to Paleoproterozoic Structural and Metamorphic Evolution in the Terre Adélie Craton - East Antarctica, poster presentation, EUG 2001, Strasbourg, abstract p. 71

Pelletier, A., Gapais, D., Ménot, R.P., Peucat, J.J., 2002. Tectonique transpressive en Terre Adélie au Paléoprotérozoïque (Est Antarctique). Comptes Rendus Geoscience 334, 505-511.

Peucat, J.J., Ménot, R.P., Monnier, O., Fanning, C.M., 1999a. The Terre Adélie basement in the East Antarctica Shield: geological and isotopic evidence for a majo 1.7 Ga thermal event; comparison with the Gawler Craton in South Australia. Precambrian Research 94, 205-224.

Peucat, J.J., Ménot, R.P., Fanning, C.M., Pelletier, A., Pecora, L., 1999b. Geochronological evidence for a Late-Archean basement in the Terre Adélie Craton, 8th ISAES, Wellington, NZ, p. 242

Rey, P.F., Houseman, G., 2006. Lithospheric scale gravitational flow: the impact of body forces on orogenic processes from Archaean to Phanerozoic. Geological Society Special Publication 253, 153-167.
Roddick, J.C., 1983. High precision intercalibration of ${ }^{40} \mathrm{Ar}-{ }^{39} \mathrm{Ar}$ standards. Geochimica et Cosmochimica Acta 47 (5), 887-898.

Rolland, Y., Mahéo, G., Guillot, S., Pêcher, A., 2001. Tectono-metamorphic evolution of the Karakoram Metamorphic Complex (Dassu-Askole area, NE Pakistan): exhumation of mid-crustal HT-MP gneisses in a convergent context. Journal of Metamorphic Geology 19, 717-737.

Rolland, Y., Corsini, M., Rossi, M. Cox, S.F., Pennacchioni, G., Mancktelow, N., Boullier, A.M., 2007. Comment on the dating of Alpine deformation by $\mathrm{Ar}-\mathrm{Ar}$ on synkinematic mica in mid-crustal shear zones of the Mont Blanc Massif (paper by Leloup et al.). Tectonics 26, TC2015, doi:10.1029/2006TC001956.

Rolland, Y., Rossi, M., Cox, S.F., Corsini, M., Mancktelow, N., Pennacchioni, G., Fornari, M., Boullier, A.M., $2008 .{ }^{40} \mathrm{Ar} /{ }^{39} \mathrm{Ar}$ dating of syn-kinematic white mica: insights from fluid-rock reaction in low-grade shear zones (Mont Blanc Massif) and constraints on timing of deformation in the NW External Alps. In: Wibberley, C.A.J., Kurtz, W., Imber J., Holdsworth, R.E. Colletini, C. (Eds.), The Internal Structure of Fault Zones: Implications for Mechanical and Fluid-Flow Properties. Geological Society of London Special Publications 299, 293-315, doi:10.1144/ SP299.17.

Ruffet, G., Feraud, G., Amouric, M., 1991. Comparison of ${ }^{40} \mathrm{Ar}-{ }^{39} \mathrm{Ar}$ conventional and laser dating of biotites from the North Tregor Batholith. Geochimica et Cosmochimica Acta 55 (6), 1675-1688.

Ruffet, G., Feraud, G., Balevre, M., Kienast, J.R., 1995. Plateau ages and excess argon in phengites: an ${ }^{40} \mathrm{Ar}-{ }^{39} \mathrm{Ar}$ laser probe study of Alpine micas (Sesia Zone, Western Alps, northern Italy). Chemical Geology 121 (1-4), 327-343.

Suzuki, K., Adachi, M., Tanaka, T., 1991. Middle Precambrian provenance of Jurassic sandstone in the Mino Terrane, central Japan: Th- $\mathrm{U}$-total $\mathrm{Pb}$ evidence from an electron microprobe monazite study. Sedimentary Geology 75 (1-2), 141-147.

Swain, G.M., Hand, M., Teasdale, J., Rutherford, L., Clark, C., 2005. Age constraints on terrane-scale shear zones in the Gawler Craton, southern Australia. Precambrian Research 139 (3-4), 164-180.

Talarico, F., Kleinschmidt, G., 2003. Structural and metamorphic evolution of the Mertz Shear Zone (East Antarctica Craton, George V Land): implications for Australia/Antarctica correlations and East Antarctic Craton/Ross Orogen relationships. Terra Antartica 10, 229-248.

Tapponnier, P., Peltzer, G., Le Dain, A.Y., Armijo, R., Cobbold, P., 1982. Propagating extrusion tectonics in Asia: new insights from simple experiments with plasticine. Geology 10, 611-616.

Tingey, R.J., 1991. The regional geology of Archaean and Proterozoic rocks in Antarctica. In: Tingey, R.J. (Ed.), The Geology of Antarctica. Oxford University Press, Oxford, pp. 1-73.

Turner, G., Huneke, J.C., Podosek, F.A., Wasserburg, G.J., 1971. ${ }^{40} \mathrm{Ar}-{ }^{39} \mathrm{Ar}$ ages and cosmic ray exposure ages of Apollo 14 samples. Earth and Planetary Science Letters 12 (1), 19-35.

Villa, I.M., 1998. Isotopic closure. Terra Nova 10 (1), 42-47.

Wendt, I., Carl, C., 1991. The statistical distribution of the mean squared weighted deviation. Chemical Geology (Isotope Geoscience Section) 86 (4) 275-285.

Wing, B.A., Ferry, J.M., Harrison, T.M., 2003. Prograde destruction and formation of monazite and allanite during contact and regional metamorphism of pelites: petrology and geochronology. Contributions to Mineralogy and Petrology 145 (2), 228-250. 